\title{
Sanatta Öznenin Biyografik İnşası
}

\section{The Biographical Construction of the Subject in Art \\ Seda Özcan Özden}

Sanatta Yeterlik Öğrencisi, Hacettepe Üniversitesi, Güzel Sanatlar Enstitüsü, Seramik Anasanat Dalı email: sedaozzcan@gmail.com (iDORCID ID: https://orcid.org/0000-0001-9181-9326

\section{Adile Feyza Özgündoğdu}

Prof., Hacettepe Üniversitesi, Güzel Sanatlar Fakültesi, Seramik ve Cam Bölümü email: feyzaozgundogdu@gmail.com DORCID ID: https://orcid.org/0000-0003-1029-7509

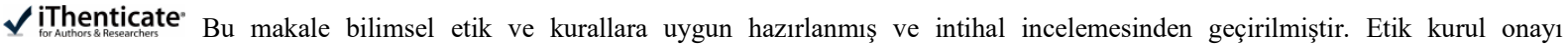
gerektirmemektedir.

Atıf (APA 7)/To cite this article

Özcan Özden, S., \& Özgündoğdu, A. F. (2021). Sanatta Öznenin Biyografik İnşası. Atatürk Üniversitesi Güzel Sanatlar Enstitüsü Dergisi, 27(47), 582-599. https://doi.org/10.35247/ataunigsed.981476

Makale Gönderim Tarihi/Received: 11/08/2021

Makale Kabul Tarihi/Accepted: 11/10/2021

Makale Yayın Tarihi/Published: 28/10/2021

Review Article / Derleme Makale

\section{Öz}

"Sanatta Öznenin Biyografik İnşası" isimli bu çalışma, insan duygusunun yaratımı olan sanat yoluyla biyografik anlatımın ifadeleri üzerine yoğunlaşmaktadır. Sanat ve özne kavramı ilișkisi, sanat öznesine odaklanarak incelenmiștir. Sanat eylemine özne kavramı üzerinden bir yaklaşım, biyografik ve otobiyografik ifadelere odaklanılan bir tavır üzerinden oluşmaktadır. Sanat eyleminde öznenin varlığı ve değişkenliği biyografik ifadeler ile yorumlanmaktadır.

Abstract

This study called "The Biographical Construction Of The Subject In Art", focuses on the construction of biographical expression through art, which is a creation of human feelings. The relationship between art and the concept of the subject is examined by focusing on the art subject. An approach to the action of art through the concept of the subject consists of an attitude focused on biographical and autobiographical expressions. The existence and the variability of the subject in the action of art are interpreted with biographical expressions.
\end{abstract}

Anahtar kelimeler: Özne, Biyografi, Sanat
Keywords: Subject, Biography, Art

\section{Giriş}

Günlük hayatta rahatça ve defalarca kullandığımız "ben" kelimesi, öznel edim söz konusu olduğunda sanat eylemindeki varlığı üzerine düşünmeye kapı açar. Ben, benlik, kendilik kavramlarının sanat üretimindeki yansımalarını biyografik ve otobiyografik anlatımlarda izlemek mümkündür. Biyografik anlatım ifadesi akla ilk yazınsal sanat eserlerini getirse de görsel ve işitsel sanatlarda da biyografik kesitlerle karşılaşırız. Çünkü özne inşası beraberinde bireyin biyografisini de sunar. Hangi sanat disiplininin ürünü olursa olsun "ben” kavramının eserdeki yeri izlenebilir.

"Eserdeki her şey yaratıcı öznenin, sanatçının yaratıcı davranışından, biçim verme etkinliğinden varlığa gelir" (Altuğ, 2018, s. 230). Heidegger (2011)'e göre; sanatçı ve eser birbirinin kaynağını oluşturur (s.9). "Eserin kaynağ1 sanatçının öznel yaratıcı edimidir" (Altuğ, 2018, s. 231). Sanat eylemine; eser, sanatçı ve alımlayıcının aynı çerçevede olması gözüyle bakıldığında, Kandinsky (2020)'nin dediği gibi: “Sanattaki ilişkiler, yalnızca dışsal forma dayalı değildir, anlam ortaklı̆̆ına bağlıdır” (s.15).

Sanat edimi öznel olduğu gibi sanat izleyicisinin algısı da öznel bir süreçtir. İzleyici eser önünden gelip geçer mi yoksa eserle özdeşleşir mi? Bu sorudan yola çıkarak sanat eyleminde özne kurguları, içselleştirme edimi üzerinden etkileşimli bir alan oluşturur.

\section{Yöntem}

$\mathrm{Bu}$ araştırmada, sanat eyleminde özne kurguları ve özne kavramı sanatçı, eser ve izleyici üzerinden irdelenmektedir. Makale kapsamında, konu ile ilgili literatür taraması yapılarak eldeki veriler doğrultusunda sanatçılar ve eserleri üzerinden özne kavramına ilişkin biyografik ifade okumaları gerçekleştirilmiştir.

\section{Bulgular ve Yorum}

\section{1. Özne Üzerine}

Sanat eylemine özne ve özneleri odak noktasına alarak baktı̆̆ımızda; "ben” kavramının izini yaratıcı olan sanatçıda, sanat eserinde ve izleyicide sürmek mümkündür. "Sanat, bilinen tüm kültürlerde sanat kuramcısı Ellen Dissanayake'nin “özel kılmak” diye adlandırdığı şeyi içerir” (Dissanayake'den alıntılandığı gibi Dutton, 2017, s. 67). Bu özel kılma hali sanatçı tarafından yaratıcı süreçte esere yüklenirken, diğer taraftan sanatçının verdiği 
ipuçları ile ya da sanatçı için referans noktası olarak kurgulanmamasına rağmen, izleyicinin kendinden bir parça bulduğu özel anlamın varlığı öznel süreçlerin getirisidir.

Sanatçı, eser ve izleyici döngüsünde, sanat eylemine özne kurguları üzerinden bakmak özne kelimesini irdeleyici bir tavrı beraberinde getirir. Dil bilgisi açısından yüklemin dayanağı olan özne; "Bir tümcede bildirilen eylemin yapıcısı ya da durumu yüklenen kimse ya da şey" şeklinde tanımlanır. (TDK, 1974, s. 636). "Fiille kurulmuş cümlelerin öznesini bulmak için, yüklem -en'li ortaç biçimine sokulur. Sonra da yükleme kimdir?, kimlerdir?, nedir?, nelerdir? sorularından uygun düşeni sorulur. Soruya cevap olan dil birliği, öznedir” (Yörük, 1985, s. 16). Yazı dilinde özne, cümlenin yüklemine bazı sorular yöneltilerek bulunur. Görsel ve plastik sanatlar için ise özne ve yüklem ilişkisi sanatçı üzerinden sorgulanabileceği gibi eser üzerinden de irdelenir.

Sanatsal edimin başrolündeki kişi olarak sanatçı, eser oluşturma eyleminin yapıcısı olarak öznedir. Aynı zamanda eser tek başına özne, nesne, yüklem birlikteliği barındırır içinde. Sanat yapıtı özne-nesne birlikteliği ile şekillenir. Kişinin yaşam ile ilişkili duygu, düşünce ve tasarımları sanatsal edimin kökenini oluşturur. Yaratıcı eylemi gerçekleştiren kişi olarak özne konumundaki sanatçı, eyleminde anlatmak istediğini özne ya da özneler üzerinden oluşturabilir. İfade ediş biçiminde öznenin konumunu sadece plastik sanatlarda değil, yazınsal eserlerde de inceleyebiliriz. Behrengi (2016)'nin “Küçük Kara Balık” yapıtının akışı bir balık öznesi üzerinden kurgulanır. Özgürlük, eşitlik, doğaya duyarlı olma gibi kavramların peşine düşme eylemini gerçekleştiren bir küçük kara balıktır ve Behrengi, çocuk masal kitabı niteliğinin ötesinde söz söyler yapıtında. "Dolayısıyla yazmak, konuşma hakkından yoksun bırakıldığınız kimi durumlarda kendinizi ifade etmenizin ve iletişimi sürdürmenizin bir aracı olabilir" (Irigaray, 2006, s. 54). Yazınsal eserlerde olduğu gibi görsel ve plastik sanatlarda özne, nesne ve eylem ilişkisi çok yönlü irdelenebilir.

"Sanat, özgün deneyimlere bağlı öznellik anlarını bir arada tutar, ister Cézanne'ın elmaları, ister Buren'in çizgili yapıları söz konusu olsun" (Bourriaud, 2005, s. 30). Rothko (2020)'ya göre, felsefe sanatla mantık bakımından aynı konuları uğraş edinir (s. 72). Bu bağlamda, özne kavramına felsefenin ışı̆̆ında bakmak, tarihsel süreçte "ben"in konumlanışı açısından konuya ilişkindir. Felsefenin temel kurgularından biri olan özne, "ilk önce (yani Aristoteles tarafından) birtakım temel özelliklerin, durum ve eylemlerin hazinesi olarak alınmış, bu bağlamda da cevher kavramıla özdeşleştirilmiştir" (Frolov, 1991, s. 376). Antik Yunan'da doğan Platon ve Aristoteles ile sistematik hale getirilen felsefenin zamanla modern felsefe olarak tanımlanmasının başlangıcında duran isim Descartes'tır.

"Descartes'la birlikte "öznellik” dediğimiz mesele doğuyor. Özne değil, öznellik dediğimiz mesele” diyen Baker (2015); Sanat ve Arzu isimli seminer dizisinde, 17. yüzyıldan başlayıp Kant’la devam eden modern özneleşme süreçlerini Deleuze bakış açısı ile eleştirel kuramın doğrultusunda inceleyerek resmin ve filmin imge ve anlam üretme düzenekleri üzerinde durur (s. 9). "Descartes'ın kanısına göre, özgün ve temel kesinlik, var olan bir şey olarak "ben” fikrinde yatar” (Lektorski, 2016, s. 75). Descartes'1n “benim özüm düşüncemdir” inancı ile "Benim, ben varım, her dile getirişimde ya da zihnimde her canlandırışımda zorunlu olarak doğrudur" önermesinde; "içimizde olup biten her şey”i özümüz saymasından yola çıkarak Lektorski, "düşünme yalnızca anlamayı değil, arzuyu ve imgelemi de, yani özbilince eşlik eden bütün ruhsal süreçleri de kapsar" düşüncesini dile getirir (Lektorski, 2016, s. 75-76). Baker (2015), “dünyayı tanımlayan ortak parametre ne olabilir?” üzerine konuşurken; cevabı Descartes'in "kuşku duyuyorum" ve "öyleyse düşünüyorum” önermesi ile "ben” olarak verir; "Ben düşünüyorum, ben kuşku duyuyorum, ben varım” (s. 30-31). Descartes’ın, öznenin kendi bilincine varıp kendi varoluşunu dolaysız bir biçimde kavramasını dile getiren, cogito'suna itirazlar çağdaşları Spinoza ve Leibniz'de okunur. Baker (2015), Leibniz’in “özne olma” konumu yaklaşımlarını birey ve perspektif ilişkisi ile nesnelerin, varoluşun, dünyanın içerisinde bakış açıları olduğunu ve bir öznenin o bakış açılarından birisine yerleştiği ölçüde özne olma durumunu anlatır: "Başka bir bakış açısındaki başka bir özne, başka bir perspektife sahip oluyor" (s. 51-52). Birey ve perspektif arasındaki bağı Harvey (1989); dünyayı bireyin bakışının bulunduğu noktadan tasarımlaması açısından vurgular (s. 253).

Descartes’ın "ben”i “şey”leştirmeye varan önermesine Kant; “Tamam kuşku duyuyorsun, zorunlu olarak düşünüyorsun, zorunlu olarak varsın, buna tamam, ama sen aynı zorunlulukla 'ben düşünen bir şeyim' diyemezsin" karşılığını verir (Kant’tan alıntılandığı gibi Baker, 2015, s. 31). "Kant ilgi odağını dışsal dünyadan onu algılayan ve içinde eyleyen özneye yöneltmiştir" (Elbeyoğlu, 2016, s. 113). "Hayır, özneyi Kant kurmuyor tabii. Özne var; bir kelimede var, cümlede var, cümlenin içinde var, dışında var” (Baker, 2015, s. 33). Kant'a göre, şimdiye kadar hep objelerin etrafında dönen öznellik, özne; artık nesneler etrafında dönecekler özneye göre olacaklardır (Kant'tan alıntılandığı gibi Baker, 2015, s. 152). Kant (2017)’ın; “Ben (özne) bir kişidir; yalnızca kendi kendimin bilincinde olmakla değil, aynı zamanda uzamda ve zamanda görü nesnesi olmakla, yani dünyaya ait olmakla" (s. 17) fragmanı burada önemli bir noktada durur.

Kant'ın öznesi Kierkegaard'ın felsefesindeki bireysel özne yerine genel olarak öznedir; Kierkegaard'ın felsefesinin sloganı haine gelen "öznellik hakikattir" veya "hakikat öznelliktir" düşüncesi felsefenin etkili temsillerindendir. Kierkegaard, idealist ya da çağdaş bilginin tümüyle nesnel, duygudan arınmış, öznel olmayan 
bir şey olduğunu savunan görüşlere karşı çıar ve bireyin her zaman için öznel yanıyla bütün bir birey olduğunu ve belli bir birey olarak düşüncelerini var oluşu ile ilişkilendirme görevine sahip olduğunu ve eylem için, uğrunda "yaşayacak ve ölecek" bir şey için gereken şey akıl ve nesnellik değil, aksine tutku ve öznelliktir görüşünü savunur. (Elbeyoğlu, 2016, s. 110-113). Badiou (2019)'ya göre; "Bir hakikat kendi öznesini oluşturur, tam tersi olmaz. Bu, onun militan boyutu olacaktır" (s. 18). "Öznelcilik, Kierkegaard ve Hegel tarafından tanıtılan bir zihinsel iklimdir" (Read, 2020, s. 41).

Özne ve biliş üzerinden okumalar yapıldığında, Lektorski (2016), bilgibilimin temel sorunlarını, bilişi bireysel bilinç yapısının belirlediği yolundaki önermeden yola çıkarak çözmeye çalışan anlayışların Marksizm öncesi modern felsefede yaygın olduğunu belirterek; "Bireysel bilinç, başka hiçbir şeye bağımlı olmayan ve başka hiçbir şeyin belirlenmediği, bütünüyle özerk bir olguymuş gibi ele alınmaktadır. Bu anlayışların öznel idealizme özgü tutumları ifade ettiği çok açıktır” (s. 68) görüşü ile karşılaşırız. Lektorski (2016), açıklamasına şu şekilde devam etmektedir:

Marksizm öncesi klasik felsefenin ve ruhbilimin çıkış noktası, öznenin özel bir şekilde kendisine içeriden ulaştığı, kendisi ve bilinç durumları konusunda herkesten çok bilgi sahibi olduğuydu. Üstelik bu bireysel öznel yansı dıș nesnelere ilişkin bilgiden farklı olarak kusursuz ve yanılgısız bilgi sayılıyordu. Gerçekten kendim hakkında başkalarının bilemeyeceği şeyler bildiğimi kabul etmek gerekir (s. 308).

Özne kavramına Marx’ın gözünden bakarsak; Marx'la birlikte ekonomi politiğin doğuşunda, nesneler düzeninden zenginliği üreten insan etkinliğinin yani bir tür insan öznelliğinin üretken faaliyeti olan emek ve sermaye olarak iki yönü vardır (Baker, 2015, s. 172). "Marksizmin özne anlayışı evrenselciydi, Marx Aydınlanmanın özerk ve birleşik özne anlayışına hapsolmuştu” (Acar Savran, 2006, s. 13). Marx’ın nesne üzerinden kurduğu kişilerarası ilişkinin kapitalist bağlamda tanımı Holden (2018)' in ifadesine göre, aynı zamanda nesneleri soyut bir denklemin iki tarafını dengeleyen bir ilişki görünüşüdür (s. 46). Holden (2018), özne'yi, Lukacs'ın bakış açısıyla da ele aldığında Lukacs'ın başkalarıyla ilişkilerimiz üzerinden özne olduğumuzu hesaba katmadığını söyler ve "biz"in kendini yaratan kolektif toplumsal öznenin idealist bir yansıması olan "ben” içinde kaybolduğunu ekler (s. 56-58).

Postmodernizm, modernizmi yadsıyarak kendisini var ederken; modernizmi Aydınlanma, Marksizm, Modernizm özdeşliğine dayanan, Descartes, Marx, Rousseau, Hegel'in de var olduğu, yekpare bir bütün olarak oluşturur. Modern paradigmada, farklı düşünürlerin eleştiri hedefi, Descartes'ın "Düşünüyorum, öyleyse varım" önermesinden kaynaklanan özne anlayışı ve buna bağlı özne/nesne ikiliğidir. "Descartes'tan Kant'a uzanan ve çeşitli varyasyonları olan bu özne anlayışı, bir yandan bilince atfettiği özerklik sayesinde özneyi bilimsel ve aklın taşıyıcısı haline getirirken, öte yandan da özneyle nesne, insanla doğa arasında bir ikili karşıtlık oluşturur”. Modern öznellik anlayışı, "kendi üzerinde düşünen, özerk ve özgür bireye dayanan bir öznellik biçimidir” (Acar Savran, 2006, s. 15-26).

Sanat felsefesi ise, sanatı insan hayatında doğal olarak ortaya çıkan bir dizi eylem, nesne ve deneyim olarak ele alan bir yaklaşımdır (Dutton, 2017, s.63). Sanat edimi sanatçının öznel sürecini kapsaması yönüyle kişisel deneyimlerin, yaşantı birikimlerinin, kişiyi derinden etkileyen bir duygunun esere yansıma potansiyelini izlemenin eylemidir. "Sanatçının öznelliği, sanat eserinde gerçek bir varlığa sahiptir” vurgusu yapan Hagman (2010)'a göre, sanatçı dışavurumunun bir sonucu olarak, kendi öznel yaşamının yansıtılmış yönleriyle yaratıcı sürece kendini kaptırarak daha fazla ayrıntıya açık hale gelir (s. 24).

Sanatı estetikleştiren görüşün, ‘ben'i özneleştiren ve gerçekliği nesneleştiren tasarımcı düşünmeden doğduğunu ifade eden Altuğ (2018); estetik nesne olarak eserin nesnelliğini sanatçının yaratıcı ediminde bulmasını Adorno'nun sözleri ile aktarır: “Kant'a göre, sanatta öznellik öznenin sanat eserine tepki verme tarzı idi; oysaki aslında öznellik sanat eserlerinin nesnelliğinin bir uğrağıdır, yani sanat eserlerini genel olarak nesnelerden ayırt eden yönüdür. Özne eserlerin biçim ve içeriğinde ikamet eder” (Adorno'dan alıntılandığı gibi Altuğ, 2018, s. 230).

Psikolojinin özne formu ise; Freud'dan önce daha çok insanların neleri istediğiyle ilgiliyken; Freud, öznenin istemesini, öznenin arzulama tarzını merkeze oturtur (Baker, 2015, s. 173). Öznenin arzu duymasının sanat ediminde yapılanışına psikoloji yaklaşımıyla baktığımızda, Hagman (2010), psikanalitik bir sanat anlayışı geliştirmedeki amacını hem sanat yaratmanın hem de sanat takdirinin ardındaki psikolojik işlevi ve motivasyonu tanımlamak olduğunu söyler (s. 18). Sanatçının diyaloğu kendi öznel yaşamının dışavurulmuş yönleriyle, dış dünyayı kendi sembolik şemaları biçiminde yeniden düzenleyen ve bağ kuran benliğinin yönleriyledir (Hagman, 2010, s. 21).

Sanatsal ifadeye duyulan gereksinim Hegel'e göre, “insanın içsel ve dışsal dünyayı, içerisinde kendi Ben'ini yeniden tanıdığı bir nesne olarak kendi tinsel bilincine yükseltme içtepisinde bulunur” (Hegel'den alntılandığı gibi Altuğ, 2018, s. 49). "İçsel bilinç süreçleri, bunların içselleştirilmesinin sonucu olarak, yani öznenin başlangıçta dışsal bir biçimde uyguladığı ve dış nesnelere yönelik olan eylemlerinin içsel düzleme "ekilme"sinin ya da taşınmasının sonucu olarak ortaya çıkar" (Lektorski, 2016, s. 347). İçselleştirme sürecini ve benin düzenleyici etmenlerini inceleyen Hartmann (2020)'a göre; bu düzenleyici etmen "iç dünya"dır ve öznel dünyanın genişliği 
bu etmendeki bireysel farklılıkları yansıtır (s. 65). Bireysel farklılıkların temelini “kendim”den söz etmek üzerine oluşturan Husserl'ın kanısına göre; karakteristik bir görünüşü, yürüyüşü, yüz ifadesine sahip olmasının yanında birey, geçmişi ve geleceği karşısında özgül tutuma sahip benzersiz bir bireysel bilincin benzersiz yaşamı olarak bütün bilişsel etkinliğin altında yatan öznel varlıktır (Husserl'den alıntılandığı gibi Lektorski, 2016, s. 96-98). Nietzsche'ye göre; kendilik; bütün arzuları, eğilimleri, güdüleri ve içgüdüleriyle bir çokluklar alanıdır; yaptığın her şey 'sen'sin; eylemlerin ve edimlerin kendiliğin ya da karakterin ifadesidir, dışavurumudur (Nietzsche'den alntılandığı gibi Talay Turner, 2021, s. 62). Ben işlevinin örgütlenmesinde ve kolaylaştırılmasında duygusal eylemin kilit rol oynadığını (Hartmann, 2020, s. 32) ve bu bağlamda, ben psikolojisini, yaşamı anlamlandıran duygulardan bağımsız tutamayacağımızı Chodorow (2019)'un duygu odaklı psikanaliz yaklaşımında okumak mümkündür;

Psikanaliz, benim "duyguların gücü” diye adlandırdığım güç sayesinde kişisel anlamı, bilinçdışı ruhsal gerçekliğimizi nasıl oluşturduğumuza ilişskin bir kuramdır. "Duygular” burada, bilinçdışı içsel yaşamımızı kuran ve kaygının yanı sıra diğer rahatsız edici ya da korkutucu duygulanımları azaltmak veya bu tür rahatsız edici duygulanımları kendiliğin dıșına atmak için bu içsel yaşamı değiștirme girișimlerimizi güdüleyen duygu merkezli öykülüleri veya ilksel öyküleri -bilinçdışı fantazileri- kapsar (s. 25).

Yaşamımızı tanımlayabilmek için varlığı yadsınamaz olan duyguların, Boyer ve Wertsch (2015)'e göre iki rolü vardır; ilki, uyarılmanın temelinde kodlama düzeyini artırarak, bellek üzerinde modülatör etki göstermeleridir; ikincisi ise lisan ve anlatının rolüne benzer ve bir duruma verilen duygusal tepki, yalnızca biyoloji ve kișilik özelliklere değil, yaşam deneyimine de bağlıdır (s. 363). Spinoza'da duygu; belirli bir güç derecesinin diferansiyeli, bir değişmedir ve bu değişme zorunlu olarak bir dereceden başka bir dereceye geçiş halidir; bir aralığın takip edilmesidir bir duygu, yani bir tür kuantumdur (Baker, 2015, s. 100). "Duyguları anladıkça aynı zamanda dünyaya yaptığımız kişisel yaratımları da anlayıp kavramsallaştırabiliriz” (Chodorow, 2019, s. 35).

Duygu, düşünce, bellekteki izler; bir başka deyişle, kendiliğin tüm boyutları özne olmanın biyografik inşa süreçleri ile ilişkindir. Böylece özne kavramına biyografi ve otobiyografi ilişkisi üzerinden bakılabilir.

\subsection{Biyografik İnşa Olarak Özne}

Biyografi, Hamilton (2007)'a göre; bir yaşamın olası versiyonlarının çokluğunda gerçek bireyselliğin tanımlanması için balık yakalamaya ait bütün terimleri hoşnut eder (s. 219). Bir balık ağının boşluklarla birlikte oluşturduğu örgü dizgisi metaforu, şimdinin gözüyle bakılan geçmişin bellekteki izlerini yansıtır; ağın yüzeyinde kalanlar, boşlukta duranlar ve boşluktan geçip gidenler biyografí yazarı için bütünlük oluşturur.

“Rönesans’tan başlayan bir süreçte bireyin yüceltilmesi bilindik bir argümandır ancak aynı süreçte özellikle sanatçı imgesinin oluşturulmasında biyografik anlatıların nasıl etken olduğu dikkatten kaçar" diyen Ünlü (2015), "Biyografi ve Biyografik Dram" adlı kitabında, öznelliğin metinselleştirilmesine biyografi, otobiyografi ve dram odağında tarihsel bir okuma sunmaktadır. Biyografi ile kesişen türleri; otobiyografi, tarih ve tarihsel roman olarak ele alan Ünlü; "Yaşamdan Sahneye: Biyografik Dram" başlığıyla biyografik özne kurgularının temsil-dramgerçeklik ilişkisi açısından biyografik oyunları inceler (s. 218).

Türkçede biyografi, “yaşamöyküsü”, otobiyografi “özyaşamöyküsü” kelimeleri ile karşılanır (Ünlü, 2015, s. 127). Yunanca bios (yaşam) ve graphēin (yazmak) terimlerinden üretilen biyografi kelimesi 17. yüzyıldan itibaren kullanılmaya başlamıştır. O zamana dek yaşam yazını, yaşamın tarihi, büyük adamların tarihi vb. isimlerle yaşamı anlatan tüm türler için kullanılırken; biyograf Samuel Johnson (1709-1784) ile bildiğimiz anlamına kavuşmuştur. Başlangıç noktası olarak büyük liderlerin ya da efsanevi kişilerin yaşam belgesi niteliğindeki mezar taşları ya da destanların biyografik düşüncesine yön veren ortak itki ölen kişinin övülmesi, büyüklüğüne tanıklık edilmesi ve gelecek kuşaklara aktarılmasıdır. Mısır'daki mezar taşlarında, Orhun ve Yenisey yazıtlarında ya da Gılgameş destanında kişilerin yaşam öyküleri, kimi zaman da kendi ağızlarından anlatılır (Ünlü, 2015, s. 35). Harold Nicolson, bu itkiyi "biyografi, anma içü̈düsünü tatmin etmek için icat edilmiștir" şeklinde ifade eder (Nicolson'dan alıntılandığı gibi Çelebioğlu, 2007, s. I). Orhun Yenisey yazıtlarına kadar uzandırabileceğimiz biyografi tarihimiz, Osmanlı'da kendini, Osmanlı Türkçesinde "Tercüman-i hal" ile karşılanan, ermişlerin hayat hikâyelerinin anlatıldığı menkıbelerde ve tezkirelerde gösterir ve Batı' da Ortaçağ' da gelişmiş hagiography'nin bir benzeri olarak görülebilir. (Ünlü, 2015, s. 127).

İlber Ortaylı, “Türk Tarihçiliğinde Biyografi İnşası ve Biyografik Malzeme Sorunsalı” isimli makalesinde, “... biyografi tek başına tarih yazımı değildir ama biyografisiz tarih yazımı da mümkün değildir" ifadesi ile "biyografik malzemenin kullanımı ve onunla zamanın örülmesi" üzerine biyografi ve tarihin kesişen alanlarını vurgular (Ortaylı, 2011, s. 142). Biyografi türü uzun yıllar tarihe hizmet eden bir alt anlatı olarak görülmüştür. Plutarch’tan başlayan çizgide gelişen yeni biyografi anlayışı sonrası bağımsızlığını ilan edip ayrı bir tür haline gelerek alt türlere bölünmekle beraber halen biyografi, otobiyografi, tarih, an1, günce, portre, roman gibi türler arasındaki ayrımlar belirsizliğini korumaktadır (Ü̈nlü, 2015, s. 172). 
Biyografi tarihiyle paralellik taşıyan otobiyografinin gelişimine baktığımızda; Plutarch'ın biyografiyi başlattığı dönemde Augustinus (M.S.354-430)'un da İtiraflar'1 ile otobiyografinin temelini attığını görebiliriz (Ünlü, 2015, s. 48). Ricoeur'a göre, “Augustinus'un incelemesi hatırlama denen mucizeye odaklanmıştır" (Ricoeur'dan alıntılandığı gibi Ünlü, 2015, s. 48). 16. yüzyılda doğrudan otobiyografi formunda yazılmasa da, Denemeler'i ile Montaigne, otobiyografi türüne hizmet eder (Ünlü, 2015, s. 49). Montaigne (1993), "Kendimizi İnceleme" isimli denemesinde; "Her konudan çok, kendimi incelerim. Benim metafiziğim de budur, fiziğim de" (s. 121) ifadesi ile kişinin kendi içine bakmasının önemi üzerine şu şekilde devam eder;

Herkesin kendi kendini tanıması öğüdü ne kadar önemli olmalı ki bilim ve 1şık tanrısı Apollon, bize diyeceklerinin özeti olarak onu tapınağının alınlığına yazdırtmış. Platon bilgeliğin, bu buyruğu yerine getirmekten başka bir şey olmadığını söyler. Sokrates de bunu Xenophanes diyaloğunda inceden inceye doğrular. Her bilimdeki zorlukları ve karanlık yanı o bilime girenler bilir yalnız. Çünkü bilmediğini bilmek için bir hayli anlayış olmalı insanda: Bir kapının kapalı olduğunu anlamak için o kapıyı itmek gerekir (Montaigne, 1993, s. 123).

Aksoy (2018), "Kurgulanmış Benlikler: Otobiyografi, Kadın, Cumhuriyet" isimli kitabında, "bir benlik meselesi" olarak gördüğü otobiyografinin tarihini inceler. Aksoy, Batı edebiyat geleneğinde Aziz Augustine'in Ittiraflar'1 ile başlayan otobiyografi türünün gerçek anlamda ilk temsili kabul edilen Jean Jacques Rousseau'nun, romantik bireyin doğuşunu müjdeyelen İtiraflar'ını, Aziz Augustine'in İtiraflar'ı ile aynı tadı taşıdığını belirtir. Rousseau'nun hayat hikâyesinin, geleneksel otobiyografi eleştirmenlerince de, "ilk modern insan”, ilk özgün birey olarak sunulduğunu açıklar (s. 17).

“Otobiyografi kelimesinin ilk defa Isaac d'Israeli'nin Miscellanies adlı kitabı üstüne 1797'de yayımlanmış bir tanıtma yazısında kullanıldığı görülmüştür. Bununla birlikte terimleşip bir yazı türünün adı olarak ilk defa 1809 ' da kullanılmıştır" (Marcus'tan alıntılandığı gibi Aksoy, 2018, s. 20-21).

Bireyin, dünyayı hayal gücü, sezgi, duyu gibi yetilerle donanmış çok yönlü kavrayışa sahip olma özelliğinin ifade bulduğu yazı türü otobiyografidir ve otobiyografi yazarı, geçmişini kalıcı kılma gayreti ile kendi hayatını metinselleştirirken, geriye dönüp baktığında onu bir bütün olarak göremez; kişisel yorum getirmek zorundadır (Aksoy, 2018, s. 13-14). Gusdorf, otobiyografiyi "kişinin kendini bilinci aracılığıyla yakalama çabası" (Benstock’tan alıntılandığı gibi Başlı, 2005, s. 91) olarak tanımlar. Bedrettin Cömert'in otobiyografiyi daha şairane “içinin tarihi” olarak adlandırdığını aktarır Oğuz Demiralp (Demiralp’ten aktarıldığı gibi Ünlü, 2015, s. 27).

Otobiyografileri bilimsel bir ilginin de odağına yerleştiren Sigmund Freud, insanlık tarihini bireyin psikolojisinin tarihi ile açıklamaya çalışırken otobiyografilerden yararlandığ 1 gibi; meslek hayatı ile düşünsel gelişimini anlatan bir otobiyografi de kaleme almıştır: “An Autobiographical Study” (Aksoy, 2018, s. 21).

Otobiyografinin bir edebiyat türü olarak önemine ilk defa dikkat çeken Alman düşünür Dilthey'e göre, insan kendini tarih içinde kimlik kazanan bir varlık olarak görür (Dilthey’den aktarıldı ̆̆ı gib Aksoy, 2018, s. 22). Öznel olanın yeniden öne çıkması, Kierkegaard'ın düşündüğü gibi, asıl gerçeğin nesnel olanın değil, öznel olanın bilgisine dayandığı düşüncesi otobiyografi edebiyatını güçlendirmiştir (Aksoy, 2018, s. 22-23). Otobiyografi bireyin kendiliğini bulunduğu andan, geçmişinin gerçeklerine bağlı kalarak anlattığı bir türdür ve bu açıdan, bireysellik ve benlikle anlatının bir ve aynı olması otobiyografinin sınırlarını çizer (Ünlü, 2015, s. 52).

Her hayat hikâyesini bir sanat eseri olarak gören Gusdorf’a göre otobiyografi bir edebiyat ürünü, yani bir sanat eseri olarak ele alınmalı, anlatılanların doğru olup olmadığı tartışılmamalıdır, çünkü otobiyografilerde kişi kendisini dışardan gözlemlenebilen eylemleriyle değil, içerden, bütün mahremiyeti içinde, ya olduğuna inandığ1 ya da görünmek istediği gibi anlatır (Gusdorf’dan aktarıldığı gibi Aksoy, 2018, s. 25). Yazarın kendi öznelliğinden, kendi alg1 düzeneklerinden, hatta ideolojisinin süzgecinden geçirerek sunduğu gerçekliğin temsil gücü o süzgecin sınırlarıyla belirlenir (Aksoy, 2018, s. 36). Diğer taraftan, otobiyografi yazarının kendinden ve geçmişinden beslenerek kişisel tarihini metinleştirme eyleminde kendini yalıtılmış olarak anlatmadığını görebiliriz. Öznel yorumun içinde barındırdığı çoğullukları Ünlü (2015), "Otobiyografi hiçbir zaman tek kişinin anlatımı değildir, her zaman kişinin diğerleri ile ilişkileri üzerine kurulur” cümlesiyle ifade eder ve Hinz'in "Otobiyografi başkalarının varlığıyla anlaşmayı gerektirir” yaklaşımını aktararak destekler (s. 179-180).

Ünlü, otobiyografiye varoluşçu yaklaşımı getiren Roy Pascal'ın “Otobiyografiler başka bir kişinin bilincinin üslubuyla benzersiz bir iç dünyayı; gerçeği anlatmasalar ya da kısmen verseler bile, onların kişiliklerinin gerçek kanıtlarını sunar" ifadesinde psikolojik bilginin özel bir yolla aktarıldığını belirttiğini açıklar. (Ünlü, 2015, s. 51). Otobiyografide, kişinin yaşantısını yeniden şekillendirdiğini söyleyen Aksoy (2018), Gilmore'un bakış açısına başvurarak şu şekilde devam eder:

$\mathrm{Bu}$ yüzden, anlatılan "ben”in arkasındaki yazan "ben”in her zaman dikkate alınması gerekir. Çünkü anlatılan "ben"i kurgulayan kişi kimi ayrıntıları seçip kimilerini görmezden gelen o arkadaki, yazan "ben”dir. Sonuç olarak, otobiyografinin konusu tekil bir bütünlükten çok, metnin içinde kendini gösteren söylemler, o söylemlerden çıkan anlamlardır (s. 36). 
Kadın otobiyografileri tarihinde kadının cinsel kimliğini ele alan anlatılardan biri olan Flying adlı kitabı ile Kate Millett, "Kendimi bulmak/keşfetmek için yazıyorum" diyerek geçmişle şimdi arasında durmadan gidip gelir (Millett'den aktarıldığı gibi Aksoy, 2018, s. 53). Bound Alberti (2019), “A Biography of Loneliness: The History of an Emotion" isimli kitabında, şair ve yazar Sylvia Plath'in bitmeyen bir yalnızlık duygusunun intiharla sonuçlanan trajik yaşamı üzerine anlatımında, çocukluktan itibaren kişiye eşlik eden duyguların kişinin yaşamında model olușturduğunu ifade ederken (s. 35), referansı Plath'in, "The Unabridged Journals of Sylvia Plath" ve "Letters of Sylvia Plath, Volume I" isimli günceleridir.

Biyografi ve otobiyografinin yazınsal sanata sıkışıp kalmadığını gördüğümüz alanlardan birisi olarak tiyatro ile karşılaşırız. Biyografinin metinden sahneye çıkıp canlı performans ile sunumu, oyuncu ve izleyicinin aynı zaman diliminde sanat eyleminin içinde olması açısından özne kurguları açısından dikkat çekicidir. İzleyicinin, seyir sırasında iletişim kurduğu oyun, kendi yaşam deneyimini de kendi içinde yeniden kurgulamasının kapısını açar. Biyografi yazınının tiyatral formu olan biyografik dram, Hubbart'a göre; bu oyunlar, başka bir öznenin dünyası ile karşılaşmanın ve onu sahnede kurmanın, yani gerçekleri eleştirel ve kurgusal bir şekilde yeniden inşa etmenin doğal sonucu olarak metakurgusal ve metinlerarasıdır (Hubbart’tan alıntılandığı gbi Ünlü, 2015, s. 177).

Kişinin yaşam öyküsünü sunan bir edebiyat türü olarak tanımlanan biyografi ve otobiyografinin varlığını sinemada, tiyatroda, müzecilikte görebildiğimiz gibi; plastik sanatlarda portre ve otoportrede izini sürebiliriz. Biyografiye sanat tarihsel bir açıdan bakıldığında, kişinin yaşam öyküsünün farklı türlerde ifade edilişini izlemek mümkündür.

\subsection{Sanatçı Okumaları}

Sanat eylemi ve insan bedeni ilişkisi üzerine gerçekleştirilen düşünsel süreç, çoklu bilim ve sanat insanı olan Leonardo da Vinci'nin Vitruvius'una kapı açabilmektedir. "Leonardo da Vinci: Zamanın Ötesi” (25 Haziran 2021) isimli belgeselde, gerçek bir Rönesans adamı olarak sınır tanımayan bir merakla insan bedeninin kesin sınırlarına erişmeyi hedefleyen Leonardo'nun, görünenin altındaki gizli yapıya, tenin örttüğü kılcal damarlara ve kaslara, ya da giysilerinden kurtulmuş insanın evrensel ölçülerine, oranlarına ya da insanın kutsal mimarisine büyük bir anatomist olarak yaklaşımından bahsedilmektedir. Leonardo da Vinci'nin iç içe geçmiş bir çember ve bir kareye yerleştirilmiş yine iç içe geçmiş iki insanı ilk çizen kişi çizimin adında gizlidir: Marcus Vitruvius Pollio. Evrenin merkezine insanı alarak, insan bedeninin, tüm sanatların ve dünyanın orantılarını barındırdığını düşünerek insan bedeninin oranlarını tapınak tasarımlarına uygulayan Marcus Vitruvius Pollio için Kemp (2004) şunları söylemektedir:

Orantının mimari tasarımındaki rolü konusunda başvurulabilecek en otoriter kaynak, Eski Romalı yazar Vitruvius tarafından mimarlık üzerine yazılmış olan tezdir. Mimarın güzellik anlayışının baş kılavuzu olan Vitruvius, insan vücudunun, kolları ve bacakları iyice açılmış haliyle, geometrik şekillerin en mükemmellerinden ikisi içine, yani bir çember ve bir kare içine yerleştirilebileceğine dikkat çekmişti. Bu şemada, vücudu oluşturan parçaların bir "ilişkili boyutlar" sistemine göre düzenlenmiş olduğu görülebilirdi. Sistemdeki her parça, sözgelimi yüz, diğer parçaların her biriyle basit bir orantı içindeydi. Vitruvius'un şemasının Leonardo tarafından yeniden şekillendirilmiş hali, onun nihai görsel gerçekleştirimi olmuş ve popüler imgelemde insan bedeninin "kozmik" tasarımının gözle görülür bir sembolü olarak yaygın biçimde kullanılagelmiştir (s. 56-58).

"Bu düşünce 1500 yıl örtülü kaldıktan sonra Leonardo ve arkadaşları tarafından yeniden anımsandı ve çizildi. Evrensel olansa Leonardo'nun çizimi oldu. Model bizzat Leonardo'nun kendisiydi. Kısacası bu çalışma aynı zamanda bir otoportreydi." (Da Vinci, 2021).

\section{Görsel 1}

Insan Bedeninin Oranları: Vitruvius Adamı

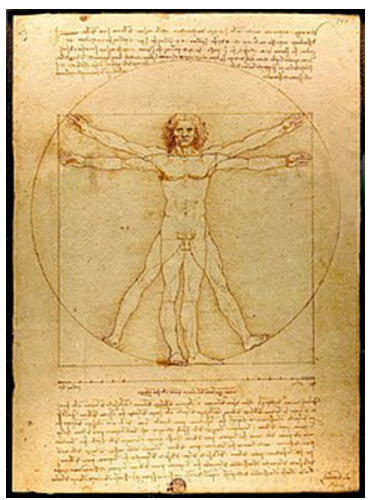

(Da Vinci, 1490) 
"Her otoportre, ne zaman, kimin tarafından açılıp okunacağı belli olmayan, bir şişenin içine konulup denize atılmış pusulaya benzer" (Sönmez, 2015, s. 181). Yazar, otoportreyi, bir sanatçının yaşamını belirleyen olguların, izlerin, işaretlerin, sembollerin yardımıyla duyumsadığı bir alan olarak son derece baştan çıkarıcı bulmaktadır. Bu açıdan ele aldığımızda Leonardo’yu da hayatının detaylarıyla ve diğer eserleriyle farklı açılardan görebilme olanaklarımız artar. Böylece izleyici ve sanatçı arasında oluşan zaman üstü ya da zaman dışı iletişim frekansı yalnızca o akışa özel, tek ve benzersiz olmaktadır. Kimi sanat eserlerinin barındırdığı frekans potansiyelinin yüksek oluşu ise sayıca fazla, geniş hayran kitlesi oluşturan bir sonuç da doğurur. Bu ister günlük kullanım objesi olsun, bir edebiyat metni, kısa bir melodi, mimari bir kesit ya da otoportre, yaratıcı kurgu içeren tasarım nihayetinde biricik ya da çok sayıda alıcıyla kurulacak davettir "pusula" sembolünde olduğu gibi. Deneyimleme ise tekrar ve tekrar belirecek yönlere göre boyutlar kazanacaktır.

Sanat eseri, sanatçı ve izleyicinin bellekteki izlerinin ve duygularının kesiştiği noktadadır ve sanat eyleminde kişiler arası iletişimin odağında durur. Altuğ (2018), kendini ifade etmeyi "Ben'in kendinin-bilgisini görünüşe getirdiği yaratıcı bir serüvene" benzetir (s. 49). Sanat alımlayıcısı, eser ile buluştuğunda eserle özdeşleşir ve bu ilişki ağında serüvenin bir parçası haline gelir. Sanat eserlerinin tecrübe edilişinin farklı seviyelerde duygu barındırdığını ifade eden Dutton (2017)'a göre; “Temsil edilen konunun uyandırdığından çok daha farklı bir havası veya tonu olan bir duygu, sanat eserine nüfuz edebilir" (s. 70). Sanat yapitının izleyici üzerindeki etkisi ve izleyicide uyandırdığı his göz önünde tutulduğunda yapıtın özne vurgusu çok yönlüdür. "Duygusal anlamda sanat eserinin ne "ifade ettiği" büyük ölçüde, izleyicinin duygusal arka planı bağlamında sanat eserine ne getirdiğine bağlıdır" (Read, 2020, s. 270). Konuyu resim sanatından örnekle ele alırsak; Edgü (2013), "Biçimler, Renkler Sözcükler" adlı kitabının önsözünde, "Gri / boz bir fon içinde gri / beyaz çizgilerle ortaya çıkan, daha doğrusu gizlenen bir attı resmin..." diyerek modelini ifade ettiği bir resme baktığında izleyici olarak neler düşünülebildiğini şu cümlelerle anlatmıştır:

"Ne buluyorsun bu resimde?"

Sorusunu cevaplamak için resme yeniden baktığımda, işte bunları görgüm; ama yalnız bunları değil. Sana, büyük bir olasılıkla, bu resmin "Sanatçının Yaşlı Bir At Olarak Portresi” olduğunu söyledim. Resmin bu insan boyutu ya da uzantısıydı beni kendine çeken. Gocunan sen oldun: Bir atta sanatçının kendisini göremeyeceğini düşünmüş olmalısın ki bana yönelttiğin o anlamsız soruyla alay ettiğimi sandın. Gerçeği söylemediğimi sandın. Oysa ona gerçeği söylemiştim. Resmin, bendeki gerçeğini. Ama buna nasıl inandırabilirdim seni? (s. 7).

Edgü'ye göre, at figürü eserde özne konumunda 'sanatçının kendisi' olarak kurgulanabilmektedir. Bu kurgu sanatçı tarafından içsel bir güdü ile oluşturulmuş ya da izleyicide bu izlenimi uyandırmış olabileceği gibi her ikisi de söz konusu olabilir. İzleyici için bir davet olan eser, onu tasarlayan hakkında bilgi kaynağıdır, bir tanışma, bir takdimdir. Bu nedenle izleyici merak eder ve burada merak; öğrenmeye, yorumlamaya varacak tetikleyici bir oyundur. Read, bu öğrenme isteğini tarif ederken sanatçının kişiliğini yok saymaktan geri duramayacağını söyler (Read, 2020, s. 271). Bir diğer taraftan izleyicinin de eser aracılığgyla sanatçı hakkında iz sürmeye gönüllü olduğu söylenebilir. Eseri incelemek, tutku uyandıran bir çözümleme oyunu gibidir. Burada cezbedici noktalar vardır ki; eser ismi, renk, bir yapı, malzeme, motif ya da tını, her zileyicinin zihninde sakladığı kendine ait anahtarlarının bu tetikleyicileri işleme olasılığı olabilir. Vitruvius Adamı'nı 1500 yıl sonra çözümlerken odağa kendini yerleştiren ressamı bugün içinde bulunduğumuz bu an içinde tekrar ele alışımızda figürün bizzat sanatçının kendisi olduğunu bilmemiz ya da “yaşlı atın” aslında ressam oluşunu öğrenmemiz bu oyunun gerçekleşmesidir. Görsel 2'de yer alan bakışlarıyla bizi odağa çeken figürün kimliğini ele alışımızdaki oyun da bizim davet edildiğimiz bir alımlamadır.

\section{Görsel 2}

Semiha Berksoy'un eşi Ercüment Siyavuşoğlu Beethoven 'in Ay Işı̆̆̆ Sonatı ’nı çalarken

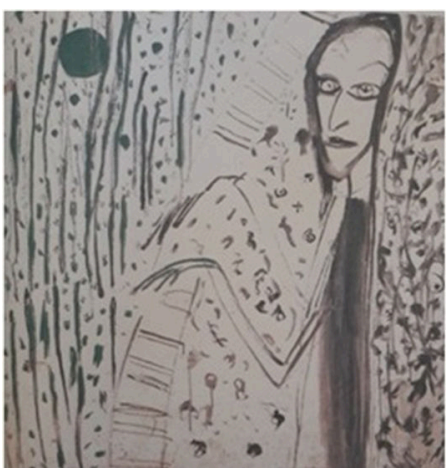

(Berksoy, 1963) 
Piyano çalan figürün izleyene bakışıyla ressamın aslında piyanistin "Berksoy’a bakışını” paylaşmakta olduğunu düşünebiliriz. Semiha Berksoy’un 1963 yılına tarihlendirilen duralit üzerine yağlıboya tablosu Çevik'in (2017) kaynağında "Semiha Berksoy'un eşi Ercüment Siyavuşoğlu Beethoven 'in Ay Işı̆̆ Sonatı 'nı Çalarken” ismiyle yer alırken bu eserde Semiha Berksoy'un, Fikret Muallâ'ya yazdığı 3 Mart 1958 tarihli mektubu okuruz: "Kocam da çok içiyor. Bugünlerde çok fena... Günde bir öğle yemeği, şöyle böyle bir tabak yiyor, sonra hep içiyor. Çok talihsizmişim. Sanatımı, duyduğum ıstırapla yaptığıma eminim. Beni tutan sanat..." (Çevik, 2017, s. 86). Sanatçının bu yakınışından birkaç yıl sonra özne olarak eşine yer verdiği resmin, Semiha Berksoy Müzesi'nde Portreler Koleksiyonunda "Canavar" ismiyle de arşivlendiğine rastlarız. Sanat edimini gerçekleştiren özne olarak Berksoy'un yapıtında özne, eşidir. Fikret Muallâ'ya yazdığı mektuplarından birinde, "Evli olduğum halde mesleğime olan aşkım beni daima hürriyetime sahip hissettirmiştir ve öyleyim" (Çevik, 2017, s. 66) ifadesi ile Semiha Berksoy iç dökümlerinden yaşamının ve sanatının etkileşimini izleyebilmekteyiz.

Mektuplar, sanatçı günlükleri, taslak notlar gibi ipuçları sanatçının üretiminin içyapısına şahit olabileeğimiz kaynaklar olabilmektedir. Berksoy ve Muallâ'da olduğu gibi iki arkadaşın içten yazışmalarıyla da görebiliriz ki, sanatçının eseri onun izlenir ya da görünmez yaşamına dair izler barındırır. Bunun tezahürü farklı yansıtma veya özdeşlik kurma biçimlerinde karşımıza çıkabilir ve her iletim biçimi bir çeşit tercümedir.

Sanatçı, bireyselliğini ve öznel olanı tercüme eder yapıtında. Sanatçının içindekilerini izleyiciye ileten gücü ile sanat, bireysellikten evrenselliğe bir yol izler diyebiliriz. Sherrie Levine, İtalyan trans-avant-garde hareketi için, "Pençesini gösteren ve bireysel ve öznel olanı yücelten bir sanat anlayışına geri dönülmesi pek çok kimse için ne büyük bir rahatlama duygusudur..." der (Gintz, 2010, s. 45). Sanatç1, bir özne kurgusu üzerinden evrensel bir mesaj verebilir. Barbara Kruger, özne olarak bir kadına yer verdiği "Aynı anda hem sana bakıp hem de soluk alamıyorum eserinde yazının da gücünden faydalanarak, bireysel çıkış noktasının sanatsal davranışın evrenselliğine uzanan yolu gösterir niteliktedir.

\section{Görsel 3}

Aynı anda hem sana bakıp hem de soluk alamiyorum / I can't look at you and breathe at the same time

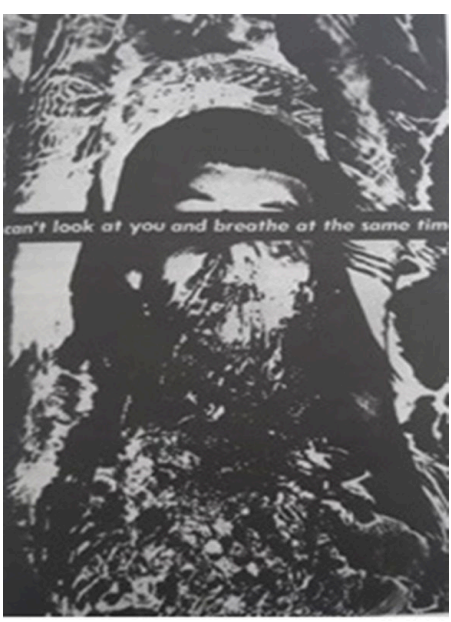

(Kruger, 1982)

Çoğunlukla kişinin hareketiyle içinde bulunduğu ortamı her ikisi de donmuş halde göstererek fotoğrafın etkisini arttırır: böylece, sırtüstü yüzen genç bir kadını yukarıdan görüntülerken, fotografik bakışın enstantanesindeki bu pozla birlikte yüzünün içinde bulunduğu suyu da "dondurur”. Ama bu katı saydamlık içerisindeki yüzücünün bakışı konuşan öznenin fikir tümcesinin yazıldığı bir bantla gizlenir: I can't look at you and breathe at the same time. Yüzücü, "Beni bakışınla hapseder, soluk almamı engeller, beni bir imgeye, bir figüre, bir fetişe dönüştürürsen sana bakışımla yanıt vermemi nasıl beklersin?” der (Gintz, 2010, s. 76).

Kruger, yüzücü figürü ile Berksoy’un aksine izleyicisine izlenmek istemediği mesajını vermektedir. Berksoy, eserinde figürün kendisine bakışını bizimle paylaşır. Görselde odak gözler iken, Kruger'in eserinde odak gözlerin gizlenişidir. Metin bantını "izlenmemek üzere bir rica" olarak algılarız. Figürün nefes alamayışını hissederiz. Akışkan ortam ve zaman donmuştur ve figür, ona baktığımız sürece bize karşılık veremeyeceğini söylemektedir. Böylece, bu eserle özneyi okuyuşumuz bu kez yüzünün gizli oluşu sayesindedir.

Bakışlardan nefes alamayacağını ifade eden Kruger figürünün karşısında, fotoğraflarında özne oarak kendini kullanan çarpıcı, farklı, aykırı, alışılmadık görünüşleriyle kendisine bakmamızı davet eden Cindy Sherman'a bakabiliriz. Sherman'ın figürlerini canlandıran bizzat kendisiyken, gerçekleri, durumları, kişileri ya da sanatsal ifadeleri kendi duyarlılığı üzerinden gerçekleştirirken burada onun kendi varoluşunu da izleriz. Sherman 
fotoğraflarında her bir figür birer otoportre iken popüler imgelerden tanıdığımız kimlikler gerçekliklerini yitirmiş, alışık olmadığımız yeni gerçeklikleriyle karşımıza çıkar. Sherman'ın fotoğraf sanatı, kendini çeşitli kostüm ve kılıklar ile bir özne olarak kullanarak çoğu film ve medya görüntülerine işaret eder. Sherman'ın "kendisinin fotoğraflarına" burada otoportre olarak baktığımızda, kendisini bir filtre ya da yeniden düzenleme yapan özne olarak görürüz. Burada yeniden düzenlenmiş gerçeklikten bahseden Cindy Sherman'dır, bir başkasının portresi değildir. Sanatçıyı özgün yapan, düzenlenmiş figürde sanatçının yüzüne ait ipuçların izini sürerken vurguyu, anlatımı, tenkidi, alayı ya da şiirselliği Sherman'ın üzerinden okumamızdır.

\section{Görsel 4}

Untitled, İsimsiz

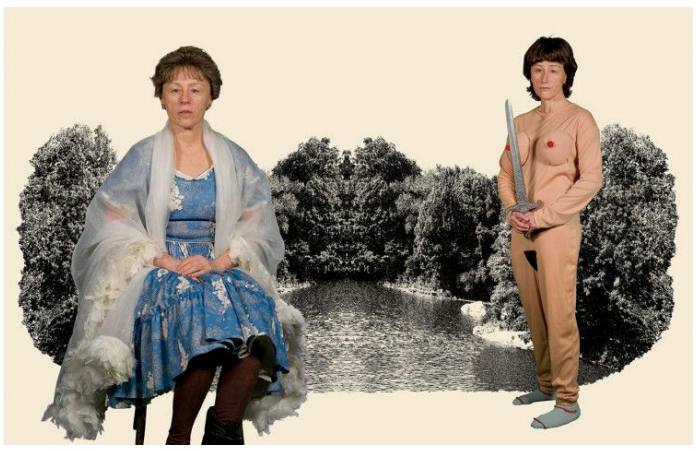

(Sherman, 2010)

Sherman gibi kendi bedeninin eserlerinde kullanan bir sanatçı da Francesca Woodman'dır. Woodman, kendisini genellikle çıplak olarak, terk edilmiş, artık yıkılmakta olan metruk mekânların içine yerleştirerek değişik kompozisyon kurguları ile çoğunu kendisi banyo ederek bastığı küçük siyah beyaz fotoğraflarda sanatsal kozasını örer (Sönmez, 2015, s. 407). Sherman'ın türlü kostüm, makyaj ve arka planlarla gerçekliği manipüle ediși gibi, Woodman da enstantene hızı ve çift pozlama ayarlarıyla fotoğraflarındaki zamanı ve kendi bedeninin var oluşu ile oynar. Oradaymış ya da değilmiş gibidir... Fotoğraftaki mekânlar ne kadar sağlam ve kalıcı bir netlikte ön planda ise, Woodman'ın varlığ 1 ise o kadar zayıf, kırgın ve geçicidir. Sherman kimliklerini hatırlarsak; başka bir zaman, başka bir mekân içindeki figürlerin gözlerinin içine bakmamız için ayarlanmıştır kompozisyonlar. Portreleri detayıyla izleyebiliriz, sanatçı orada karşımızdadır ve hikâyeyi okumamız için davetkardır. Ancak Woodman fotoğraflarında, kendisi oradan ayrılıyordur ya da henüz ayrılmıştır. Özne mekânı adeta giyinir, mekân olur ve ardından kaybolur. Sanatçı kendine ayırdığ 1 ile ayrılıyordur ve izleyicide kalan, zaten önceden kendisinde olandır.

\section{Görsel 5}

Untitled, Isimsiz

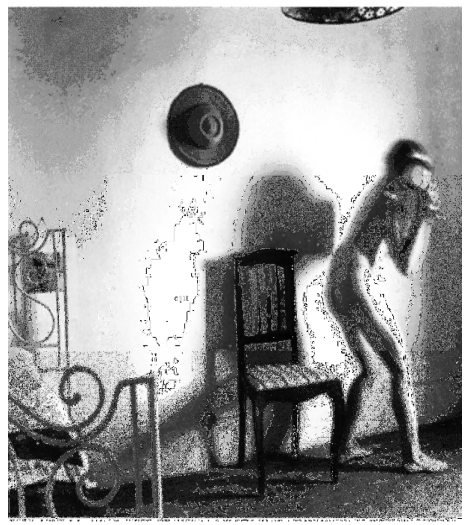

(Woodman, 1977)

Özne kurgularının bedensel anlatım ifadesi üzerine örnek sunan sanatçılardan birisi de Özlem Şimşek’tir. Performatif fotoğraf ve video işleri üreten Şimşek, çalışmalarını portre sanatından beslenerek oluşturur. "Kendi bedenini kullanarak gerçekleştirdiği fotoğraf ve videolarında Özlem Şimşek, izleyiciyi tarihsel boyut taşıyan görsel verileri kadın kimliği, cinsiyet, modernlik ve temsil üzerinden yeniden düşünmeye çağırır” (Antmen, 2017, s.70). 


\section{Görsel 6}

Kadın Portresi

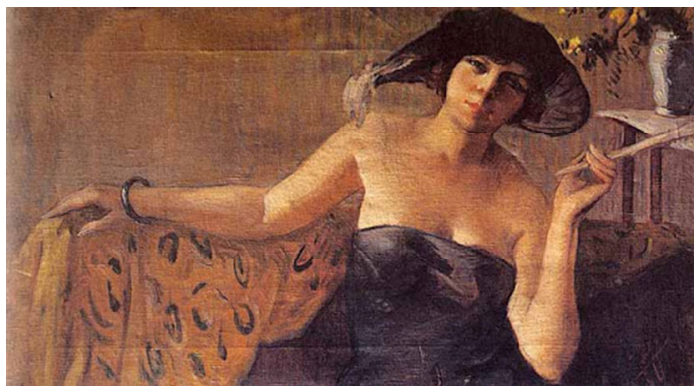

(Çallı, t.y.)

\section{Görsel 7}

Sigaralı Kadın

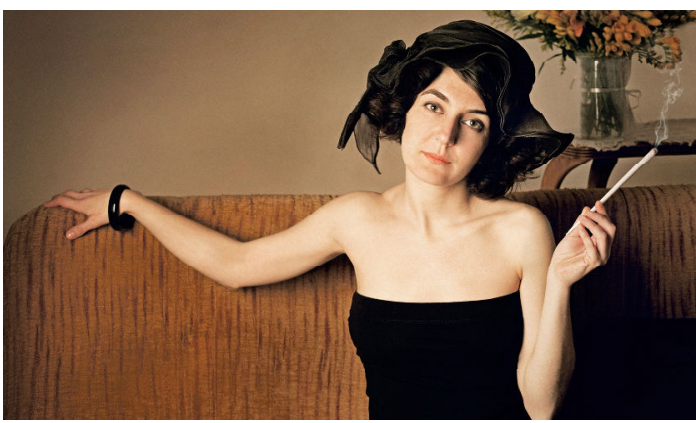

(Şimşek, 2011)

1914 Kuşağı'na adını veren ressam İbrahim Çallı, değișen bir toplumda aşama aşama özgürleşen kadınların ruh halini yansıtabilmiş bir ressam olarak, Kadın Portresi resmi ile kendine özgü duyarlı yaklaşımın kadın figürü üzerinde ifadesini bulan resimleri arasındadır. Çallı'nın Kadın Portresi cesur ve cüretkâr bir “yeni kadın” portresi olarak dikkat çeker (Antmen, 2017, s. 53). Modern Türk ressamlarının yaptığ 1 portrelerin fotoğraf ve video olarak yeniden üretimi üzerine çalışan Özlem Şimşek için İbrahim Çallı’nın Kadın Portresi ele aldığı Görsellerden biridir. Özlem Şimşek, fotoğrafın poz veren için de, fotoğrafçı için de performatif olduğunu belirterek, çalışmaları ile ilgili şu sözleri söyler; “... fotoğraf çekmeye başladıktan sonra fark ettim ki fotoğrafla kendim bir hikaye kurabiliyorum ve bu benim bakışımı yansıtabiliyor. Bu, temsilin içinde benim söz söyleme beyanında bulunma, kendime dair durumumu gösteriyor." (Tokmak, 2020). Burada Woodman'ın fotoğrafla ilişkisini anımsıyoruz: Anlatacağı ya da kuracağı şeyleri ne yazılı ne de sözlü bir frekansla iletemeyeceği için fotoğrafin diline varmış sanatçı mekânlardan hikâyeler alır ve kaybolur gibidir. Şimşek'in giyindiği özneler de böyledir, ancak Sherman'ın figürlerinden farklıdır. Bize tanıdık gelen figürler Sherman tarafından tasarlanmışken; Şimşek, başka sanatçıların tasarladıkları kadınları tekrar deneyimlemektedir.

Şimşek'in kendisini özne olarak konumlandırarak kurguladığg yeniden üretimlerine Antmen (2017), şu şekilde değinmiştir;

Sigaralı Kadın (İbrahim Çallı’dan Sonra) (2011) adlı videosunda Özlem Şimşek, Çallı'nın cesur ve cüretkâr 'yeni' kadınını kıyafetinden ziyade, özellikle yüz ifadesi ve vücut dili üzerinden yeniden canlandırır. Bu yapıtı ilginç kılan noktalardan biri, Şimşek’in kurguladığı video atmosferi içinde görüntünün bir 'eski zaman kadını' şeklinde algılanmasıdır. Şimşek'in bedeni, böylece, bu eski ve yeni çatışmasının tam ortasındaki gerçekliğin ifadesi olarak şizofrenik bir durumu gündeme getirir. ... Böylece her bir yeniden üretim, sanatçının da belirttiği gibi, verili dili tersine çevirerek farklı bir okuma yapmaya çağıran bir tür davete dönüşür (s. 53).

Portre ve otoportrelerde öznellik okumaları üzerine verilebilecek sayısız örnek bulunabilmektir. Konuya ilişkin bir diğer örneği, Ali Akay’ın, "Sanatın ve Sosyolojinin Ruh Hali” isimli kitabından yola çıkarak verebiliriz. Akay (2001), "Portrenin Kendi Öznelliği: Parçalanmalar” başlığı altında, Arzu Başaran'ın Galeri Apel'de açtığı kişisel sergisi üzerine konuşur. Serginin, "bir sanatçının ne kadar kendisiyle ilgili olarak çalışmalara başladığını ve bu şekilde de kendi kendisini ne kadar çoğullaştırdığını” gösterdiğini ifade eden yazar, Arzu Başaran'ın otoportleri için şunları söyler: “Özne kendi öznesini kendi parçalanmışlığında meydana getiriyor. Özdeşliğin kendisi portrenin kendisi olarak duruyor. Kendi mevcudiyetini oluşturuyor" (s. 201-203). Akay’ın "kendini çoğullaştırma” olarak tespit ettiği durumu bu yazı kapsamında örnek verilen tüm eserler için okusak da, Başaran’ın portrelerinde 
kullandığı tarz, özdeşliği daha da kolaylaştırır. Diğer Başaran portrelerine de bakıldığında, izleyici kendini kolayca tanır. Zihinde kalmış o siluet ile tuvalde karşılaşılan siluetin örtüşme anı portreyi tamamlamaktadır.

\section{Görsel 8}

Isimsiz

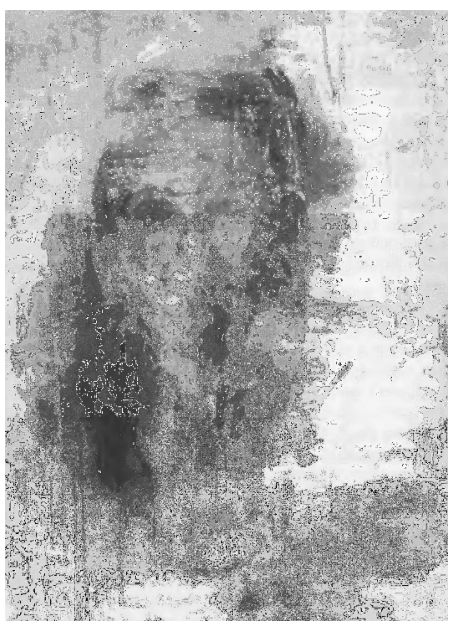

(Başaran, 2000)

Özne kavramına, eserde kullanılan malzemenin konumu olarak bir yaklaşım ile bakıldığında, Roy Lichtenstein'in Brushstroke resimleri konuya ilişkin bir başka bakış sunar. Boyanın karakterine ait bir şey söylüyor olması ile özne kurgusunu malzemede okumak mümkün görünmektedir.

\section{Görsel 9}

Brushstroke

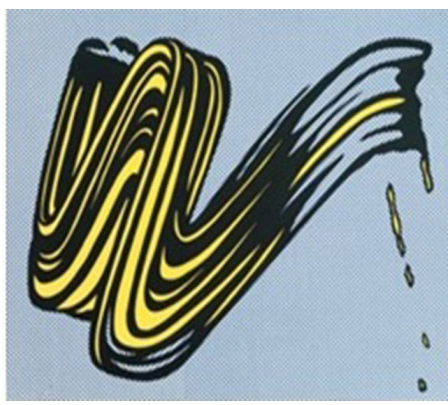

(Lichtenstein, 1965)

İlk ilgi her zaman resimlerin malzemesi olan ancak bir şekilde ressamlar tarafindan gizlenen ve burada öznenin yararına ortaya çıkarılan boyanın fizikselliğine yöneliktir. ... Boya özne olduğundan, sanatçı bir ressamdır ve en temel sanatsal eylem kopyalama, taklit etme, tasvir etme, işaret etme değil boyamadır (Danto, 2019, s. 128).

Danto (2019), bu tavrı, "boyanın kendi yaşamını kendisinin yaratmasına izin vermek" olarak ifade eder ve Lichtenstein'ın Görselleri hakkında, oldukları şeyin özelliğini taşımaması üzerine şunları ekler; "Örneğin bunlar, firça darbelerini gösterir, ancak firça darbelerinden oluşmaz; izleyici gösterilenle gösterme biçimi arasındaki çelişkinin farkına varsın diye yüzey ve özne neredeyse karşıttır” (s. 129-130). Odak noktamızı değiştirerek bu durumu bir kaligrafi gösterisiymiş gibi algılayabiliriz. Harfler, semboller, işaretler, grafikler ya da firça darbeleri temsil misyonlarından apayrı bir noktada başlı başına potansiyel kazandıklarında, kimlikleri ayrı birer değer kazanır. Bir firça darbesindeki melodi duyulabilir ya da düz bir çizginin gölgesi görülebilir hale gelir ki bu halleriyle başlı başına kimlik kazanmış olurlar.

Sanat ediminde özne kurgusu, hazır malzeme ve anlatım ifadesi açısından incelendiğinde, malzemenin kurduğu bağlantılar ile izleyiciyi esere davet eden yaklaşımlar görebilmekteyiz. "Hazır-yapımlar aynı anda hem sanat yapıtı hem de sıradan nesne olabilme özellikleriyle, değişmez bir kimlikten ve tanımdan yoksun olarak çift kimlikli nesnelerdir" (Alioğlu ve Bayrak, 2019, s. 73). Sanatçının kurduğu bağlam her zaman öncelikli rehber olsa da nesnenin karakteri, anısı, tanışıklığı bağımsız bir sinyal göndermeye devam edecektir. 


\section{Görsel 10}

Hang Up / Asılmış

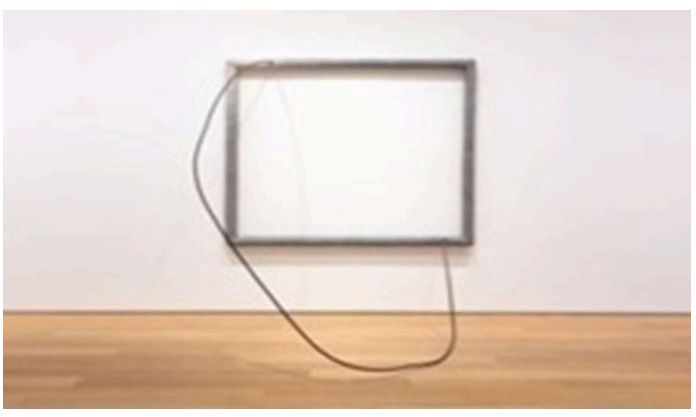

(Hesse, 1966)

Eva Hesse, Hang Up / Asılmış isimli eseri ile izleyiciyi özne olarak esere dâhil eder. Hopkins (2018), bezle sarılmış bir çerçeveden çıkıp, çelişkili şekilde, çerçevenin boşluğunu ortaya kusarcasına izleyicinin alanına doğru uzatılan üç metrelik devasa metal tel halkasıyla Hesse'nin eserini “Takıntı" ismi ile Hesse'nin geçmişiyle okur (s. 169);

Somutlaştırdığı varoluşsal ikilem ne olursa olsun Takıntı'nın boşluğu şekillendirmesi duygusal sözlerle yorumlanmaya muhtaçtır; Hesse'nin yapıtının psikanalitik tanımı, yapıtın üretildiği yıl sanatçının babasının ölmesi ve önemli bir belirleyici etken olarak bu durumun Hesse'in annesinin intiharıyla ilgili anılarının canlanmasidır (Hopkins, 2018, s. 170).

Tel halka ve çerçeve arasındaki boşluğa atacağımız bir adımla birlikte bulunduğumuz ortamdan ayrılıverecek oluşumuz çok açıktır. O boşluğu ayarlayan, ilk deneyimleyen ve içini dolduranın Hesse olduğunu bilişimiz, ona doğru atılmış bir adımımızdır. Çerçeve, tuvale ya da bir kadraja referans verir, çünkü duvara asılıdır. Bir yüzey parçası simgesini taşırken aslında içi boştur, taşıdığı bir ekran yoktur. Aslında çerçeve bizi içine çekmiştir, çevreler ancak çerçevelemez. Karşımızda boş bir yüzeye bakarken, koordinatları belli olmayan bir atmosferi deneyimlediğimizi hissederiz.

Sanat eyleminde alımlayıcı öznenin katılımı ile eser, Altuğ (2018)'a göre, "aslında kendi hayatını yaşar" (s. 216). İzleyiciyi esere özne olarak açıkça davet eden çalışmalara verilebilecek başka bir örneği, Deniz Gül'ün “Arzunun Kanatları / Wings of Desire" ile oluşturmak mümkündür. Gül, bu projesi ile, "Dünyadan Çıkış Yolları" başlıklı, 18-21 Mayıs 2017 tarihli Cappadox festivali kapsamında Kapadokya'da gerçekleştirilen sergi dahilinde, heykel yerleştirmesini Keyişdere Vadisi’ne konumlandırarak izleyiciye fiziksel olarak esere dahil olma imkânı sunar.

\section{Görsel 11}

Arzunun Kanatları / Wings of Desire

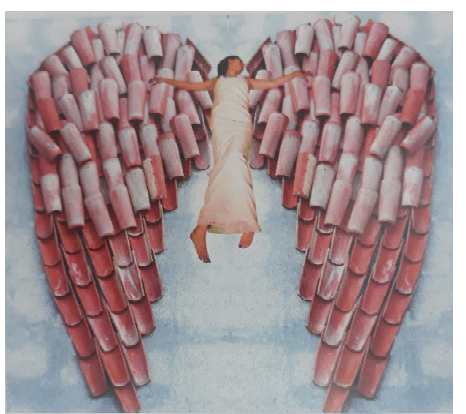

(Gül, 2003)

"Şehir dokusunda görmeye alışık olduğumuz çatıları oluşturan kiremitler bu yerleştirmede yere çakıllyor. Yerden havalanamıyor, büyük bir şölenle, şehvetle toprağın üzerinde bir doku oluşturuyor, coğrafyayla birleşiyor" (Vardar, 2017, s. 76). Kendi bedenini eserinde özne olarak kullanan Gül, izleyici deneyimi için davetkâr olarak izleyicinin de eserde özne olarak konumlanmasını kurgular. "Başlığını Wim Wenders'in aynı adlı ikonik filminden alan ve kiremitlerin melek kanatları formunda dizilmesinden oluşan bu heykel yerleştirmesi izleyicilerin katılımıyla tamamlanıyor. Proje izleyiciye, aynı zamanda, bir tür çocuk oyunu deneyimi de öneriyor" (Vardar, 2017, s. 76).

Sanat edimine, "seçilmiş, doğal ortamından ve bağlamından ayrılmış olan gerçek nesneler, sanatçısı tarafindan eşsiz ve biricik birer sanat yapıtına dönüştürülür" (Alioğlu ve Bayrak, 2019, s. 61) yaklaşımı ile bakıldığında Arazi Sanatına değinmek mümkündür. Bu anlayışta izleyici hareket içinde sanat yapıtının içine girer, çevresinde ve etrafinda dolaşabilir (İrgin, 2018, s. 98). 
Land Art; Arazi Sanatı, Yeryüzü Sanatı, Çevre Sanatı, Toprak Sanatı gibi çeşitli terimlerle anılan bu yaklaşımın temelinde çevreci hareket vardır. Arazi Sanatı'na yönelmiş sanatçıların genel tavrı; doğada bizzat varlığının izi üzerinden kurgulanan performatif nitelikli çalışmalar olarak doğanın döngüselliğine göndermede bulunması ve aynı zamanda insan kültürünün doğa üzerindeki hükmetme duygusunun simgesi olan sınırları gündeme getirmesidir (Antmen, 2019, s. 251-255). 1960'lar ve 1970'lerdeki Kavramsal Sanat' in bir parçası olarak gelişim gösteren Arazi Sanatı'nın en belirgin özelliği, doğrudan doğanın içinde üretilen sanat eserleri olmalarıdır diyen Hodge (2020); doğal malzemelerden yararlandıkları farklı ve dişavurumcu işler ortaya koyan sanatçıların bazılarının toprağı şekillendirdiğini, geçici işaretlerle doğada bulundukları yerleri belgelediğini, bazılarının ise taş, toprak, dal parçaları ve kayaları galerilere taşıyıp enstalasyonlar yaptığını ya da açık havada sergilediklerini ifade eder (s. 188). Bu bağlamda akla gelen ilk örnekler arasında, İngiliz sanatçı Richard Long'un doğada yaptığı yürüyüşler ve bu yürüyüşler sırasında doğal malzemeyle yaptığı enstalasyonlar yer alır (Antmen, 2019, s. 255).

\section{Görsel 12}

Yürüyerek Yapılmış Bir Çizgi /A Line Made ByWalking

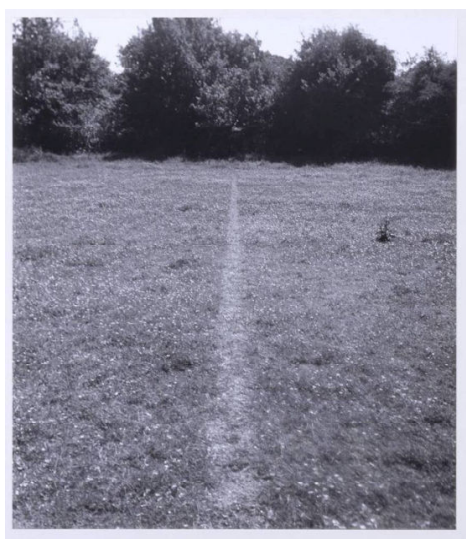

(Long, 1967)

"Long için, eğer çalışmasını gerçekleştirebileceği taş, ağaç dalı ya da yosun gibi malzemeler yoksa, olanakları dâhilinde farklı yöntemler kullanarak herhangi bir iz bırakmak her zaman olasıdır" (Güner ve Ataman, 2016, s. 70). Kendi varlığını iz kavramı ile doğada kurguladığı oluşumları, Long'un cümleleriyle "Beş Altı Sopaları Aldı (1980) ” başlığı ile aktarır Antmen (2019);

Benim sanatım bu geniş dünyada çalışmakla, neresi olursa olsun, dünya üzerinde olmakla ilgili. ... Sanatım, kendi duygularım, kendi içgüdülerim, kendi boyutlarım ve kendi fiziksel adanmışlığımla ilgili. ... Bir sanatçı olarak benim yeteneğim bir arazide yürümek, ya da yere bir taş bırakmaktan ibarettir. ... Yürüyüş toprağın üzerinde iz bırakır, bir fikrin peşinden gider, gündüzü ve geceyi izler (s. 259-260).

Biyografik ya da otobiyografik özne kurgularını sanat eserinde görebileceğimiz bir başka örnek, Tracey Emin'in “Everyone I Have Ever Slept With 1963-1995” eseridir. Sanat nesnesinin sanatçının yaşamından kesitler sunması otobiyografik okumalara firsat verir. Çadırın girişinin açık olması izleyiciyi özne olarak esere dahil eden bir tavır olmakla birlikte, bir sanat nesnesi olarak çadır, sanatçının bedeninin metaforik bir ifadesidir. Metaforu, özellikleri aracılığıyla küçük sanat yapıları olarak tanımlayan Danto (2019)'ya göre; “metaforlar sadece özneleri temsil etmez fakat temsil biçiminin özellikleri özneyi anlamaya katkıda bulunmaktadır”' (s. 211). Emin'in çadır metaforu özne kurgusunu yansitır.

\section{Görsel 13}

Everyone I Have Ever Slept With 1963-1995 / 1963-1995 Yillarl Arasında Uyuduğum Herkes
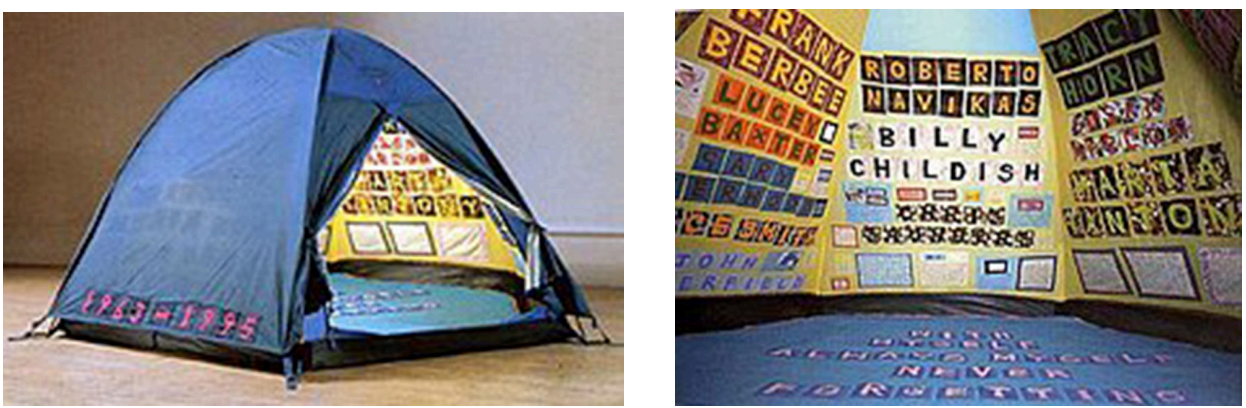

(Emin, 1995) 
Yaşadığı travmaları ve geçmiş olayları itiraf etme aracı olarak kurguladığı eserinde, Tracey Emin, 1963-95 yılları arasında yattığı 102 ismi nakış ile işlemiştir. Nakış ile işleme kadınsal olana vurgu yapmak amaçlı olmasının yanında, izleyicinin eseri görebilmesi için çadırın içine girmesi gerekmektedir. Çadır ile kendi bedenine göndermede bulunmanın bilinçli kurgusu sayesinde izleyici ile sanatçı arasında bir, empati ya da özdeşleyim kavramı olan, einfühlung bağı kurulmaktadır (Koruç’tan aktarıldığı gibi Bahadır, 2020, s. 104).

Sanatçı ve bedensel ifadeyi düşündüğümüzde, bedene odaklanan sanat olarak performans sanatından söz etmemek kaçınılmazdır. Beden Sanatı, Happening, Aksiyon gibi çeşitli başlıklar altında gündeme gelmiş, Sitüasyonizm, Fluxus, Feminist Sanat, Arazi Sanatı gibi farklı akımlar dahilinde uygulanmış olan Performans Sanatı, 20. yüzyılın ikinci yarısında disiplinlerarası özelliğiyle dikkat çeken ve ancak 1970'lerde başlı başına bir tür olarak kabul edilmeye başlayan bir sanat olup, en belirgin özelliği; bedeni sanatsal bir dil olarak kullanmasıdır. Disiplinlerarası ilişkinde tiyatro, dans, şiir, müzik gibi sınırsız yaklaşımlar bütünü olsa da, özünde Kavramsal Sanat'ın bir kanadı olarak gelişme göstermesiyle, tiyatro ile ilişkisi görsel sanatlarla olan ilişkisinden daha mesafelidir (Antmen, 2019, s. 219). Akla hiyerarşik bir üstünlük tanımaktansa bedeni deneyimlemeye öncelik veren yaklaşımıyla performans sanatı, izleyicinin sanat eylemini bir gösteri değil, gerçek bir deneyim olarak algılamasını sağlar (Antmen, 2019, s. 223).

Fransız sanat kuramcısı ve küratör Bourriaud (2005), “İlişkisel Estetik” isimli kitabında; sanat eyleminin ilişki ağının, "Her ne olursa olsun, sanatın satranç tahtasında oynayan en hızlı parti, karşılıklı-eylem (interactives), biraradalık ve ilişkisellik kavramlarına bağlı olarak" geliştiğini ifade eder (s. 11). Bourriaud (2005), "Fluxus happening'leri ve performanslarıyla kuramsallaştırılan seyirci 'katılımı', sanatsal pratiğin bir değişmezi haline geldi” sözleriyle izleyici kavramını, katılımcıya dönüştürür (s. 41). Performans sanatını meydan okuyan ve etkili işler olarak değerlendiren An ve Cerasi (2021)'ye göre; performans sanatındaki "bu fiziksellik, sanatçı bedeni ve onun aracılığıyla kendi bedenimize dair açığa çıkan bilinç, en güçlü biçimde performans sanatıyla aktarılmaktadır" (s. 95). "Sadece gözlemci olmadığımıza ama yaşayan, nefes alıp veren bir sanat yapıtının bir parçası olduğumuza inanmamiz gerekir" (Gompertz, 2020, s. 62).

Sanat alımlayıcısını düşünmeye sevk eden ve sanat eylemine izleyicinin de katılımını kurgulayan Performans sanatından bir örnek, Marina Abramović ve Ulay çiftinin “Imponderabilia” performansları üzerinden verilebilir.

\section{Görsel 14}

Imponderabilia / Ölçülemeyen
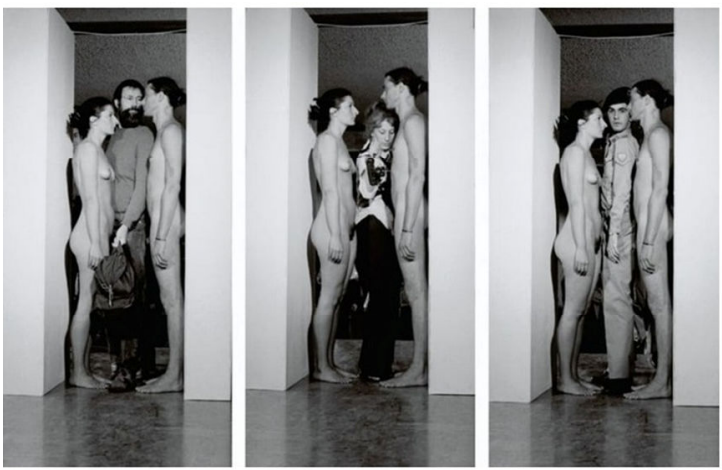

(Abramović, 1977)

Karşılıklı ve çıplak olarak kapı eşiğinde duran sanatçı çift, sanat ediminde özne inşalarına bir kapı imajı yükleyerek, izleyicinin aralarından geçmesi ile sanat eylemine katılımını kurgular. Kapı eşiğinin dar olması sanatçıların ve izleyicilerin bedenlerinin temas etmesi koşulunu doğurur. Kendi bedenlerini kullanarak gerçekleştirdikleri performansta eşikte durmaları biyografik bir okumayı beraberinde getirir; metaforik olarak sanatçı çiftin aşk ilişsilerinin eşiği anlamı yüklenebilir. Sanat alımlayıcısı ve sanatçı ilişkisinin sınırlarını zorlayan “Imponderabilia" / "Ölçülemeyen”, izleyicinin eşikten geçerken hangi cinsiyetteki sanatçıya yüzünü döneceği seçimini de ölçer.

Sanat eyleminde özne kurgularının seramik diliyle oluşturulması üzerine Maarit Mäkelä, "Holy Family" eseri ile konuya ilişkindir. Maarit Mäkelä’nın aile imajlarını eserinde vurgulaması biyografik bir yaklaşımı hissettirir. 


\section{Görsel 15}

Holly Family / Kutsal Aile
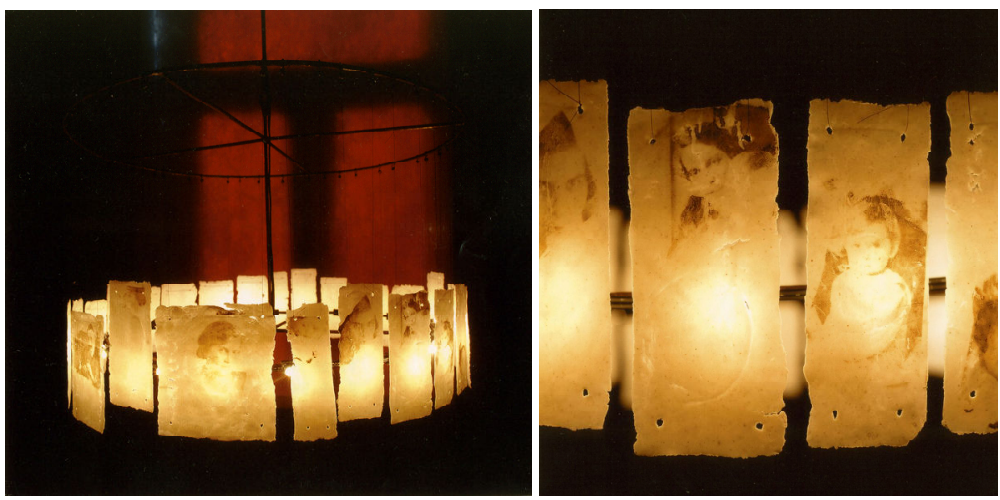

(Maarit Mäkelä, 1999)

Maarit Mäkelä’nın kemik porselen plakalarla yapmış olduğu düzenlemede çıartmayla uygulanan siyah-beyaz fotoğraf görüntülerinin niteliğinin, tasarlanan vurgu nedeniyle düşürüldüğü görülmektedir. Plaka üzerine serigrafi çıkartmalarla uygulanan görüntüler ışık geçirgenliğinin etkisiyle gizemli bir etki taşımaktadır (Çakır, 2004, s. 80). İzleyicisi için, Mäkelä'nın bu belli belirsiz aile imajlarında, Arzu Başaran'ın otoportrelerindeki gibi algı inşası söz konusu olabilir. Aile fotoğrafları geleneğinin ilk yıllarına ait bu yüzler objektife bakmaktadır. En bakımlı halleri ve keskin bakışlarıyla objektife bakarlarken onların anlık belirişleri porselen yüzeylere sabitlenmiş̧ir. Herhangi bir kurgu ya da mesaj kaygısı olmadan, yalnızca belgelenen bu yüzler çoğumuzun tanıdık bulduğu imajlardır. Onlar artık yaşamayan yüzlerdir. Onların artık olmayışını hissetmemiz en vurucu gerçektir. Draaisma (2018)'ya göre; fotoğraf, bir bellek metaforu olarak hatıralarımızı gerçekliğin tam ve kalıcı kopyaları olarak tanımlar (s. 185). Bu yaklaşımdan yola çıkacak olursak; Maarit Mäkelä'nın fotoğrafları daha kalıcı kılma arzusu güderek seramiğin malzeme olarak verdiği imkânları kullanmış olduğu düşünülebilir.

\section{Sonuc}

$\mathrm{Bu}$ yazı kapsamında, biyografi yaklaşımı altında ele alınan tüm değerlendirme ve üretimler öznenin tanımlanma ve ifade edilmesine yönelik kadrajlardan incelenmiştir. Dutton (2017)'un tarifiyle sanattan beklentimiz “ $\ldots$ çıplak bir his olarak yalnızca duygu değil, o duygunun bireye ait sanatsal ifadesi, yani duyguların teknik, yapı, denge ve seslerin karışımı yoluyla sanatta nasıl gün yüzüne çıktığı” (s. 266) ile ilgilidir ki, bu araştırmada da her bir sanatçı incelemesi örnek eserlerle öznenin biyografik inşasına odaklanır. Kuspit (2010)'e göre; "sanat, ruhun derinliklerine inen bir sualtı aracıdır, ruhun içinde yüzen tuhaf duygulara ilişkin bir kavrayış sağlarken, basınca da dayanır" (s. 126). Yaratıcısı olan sanatçıdan doğan eseri, önce sanatçının duygularını barındırır. İzleyici ile buluștuğunda, eserin yarattığı duygu etkisi Altuğ (2018)'a göre; “ben'in kendini aşmasının başlatıcısıdır; ben'in en yüksek imkânlarına doğru açılmasının, ben'in kendini insanlığa doğru aşmasının başlatıcısıdır" (s. 259).

Sanat eseri paylaşılabilir ve iletilebilir olma özelliğine sahiptir. Eserin tekilliği ile bireysel bir duygu ilişkisi içinde seyirci, eserin dünyasına açılır ve orada muhafaza edilen duygu durumunu kendi duygusu olarak yeniden üretir, böylece bu duygu durumu, seyreden öznenin içinden onun ötesine geçerek insanlığın tümelliğine ulaşır (Altuğ, 2018, s. 259). Sanatın iletişim ağında; tekillikten çoğulluğa, çoğulluktan tekilliğe bir akıştan söz edilebilir. Öznellik sanat üretimi sürecinde nesnel bir başkalık halinde somutlaşmış olsa da bu başkalık içinde kendi karakterini koruyarak "ben"in ipini bırakmaz. John Locke'a göre; "İnsan ancak kendine ait, onu diğerlerinden ayıran geçmişiyle bağlantı kurabildiği ölçüde bireydir”' (Locke'den aktarıldığı gibi Boyer ve Wertsch, 2015, s. 10).

Bu yazıda, "ben" kavramının sanatçı, eser ve izleyici ilişkisi içinde, özne üzerinden biyografik okumalar sağlayan bakış; "Sanatçı Okumaları" başlığı altında incelenmiştir. Bu doğrultuda; bir otoportre olarak görülen 1490 tarihli Insan Bedeninin Oranları: Vitruvius Adamı ile Leonardo da Vinci; özne olarak sanatçının eşini kurguladığı resmi ile Semiha Berksoy; eserde özne olarak kendi bedenini kullanmayı tercih eden Barbara Kruger, Cindy Sherman, Francesca Woodman ve Özlem Şimșek; portre ve özne özdeşliği açısından Arzu Başaran; malzemenin eserde özne olarak yer alması açısından Roy Lichtenstein; izleyiciyi de esere özne olarak dahil eden Eva Hesse ve Deniz Gül; kendi yürüyüşünün izini doğaya bırakan tavrı ile Richard Long; kendi geçmişini ifşa eden tavrı ile aynı zamanda izleyiciyi eserin içine alan Tracey Emin; performans sanatının sanat eylemine izleyicinin katılımını kurgulayan ve izleyiciyi düşünmeye zorlayan tavrı ile Marina Abramović ve Ulay, seramik bünyede yüzey çalışmalarında aile imajları ile biyografik okumaları vurgulayan Maarit Mäkelä bahsedilen sanatçılardır.

Geçmiş okumalarını eser kurgusunda özne üzerinden oluşturan sanatsal pratikler, biyografi ve otobiyografinin farklı türlerde nasıl kullanıldığının bir göstergesidir. Sanat ediminde, kendi bedenini eserin öznesi olarak 
kurgulayan eserlerin yanı sıra, izleyiciyi de özne konumunda esere dâhil eden sanatsal tavır, özne kavramının biyografik inşa yaklaşımını yansıtır.

\section{Kaynakça}

Abramović, M. (1977). Series-works with Ulay: Imponderabilia. [Fotoğraf]. Wikiart. https://www.wikiart.org/en/ marina-abramovic/imponderabilia

Acar Savran, G. (2006). Özne-yapı gerilimi, maddeci bir bakış. Kanat Kitap.

Akay, A. (2001). Sanatın ve sosyolojinin ruh hali. Bağlam Yayınları.

Aksoy, N. (2018). Kurgulanmış benlikler; otobiyografi, kadın, cumhuriyet. İletişim Yayınları.

Alioğlu, N., \& Bayrak, B. (2019). Çăgdaş sanatta anlam sorunu üzerine bir deneme. Literatür Yayınları.

Altuğ, T. (2018). Son bakışta sanat. Yapı Kredi Yayınları.

An, K., \& Cerasi, J. (2021). Kim korkar çağdaşs sanattan. (M. Üstünipek, Çev.). Hayalperest Yayınevi.

Antmen, A. (2017). Kimlikli bedenler; sanat, kimlik, cinsiyet. Sel Yayınc1lı.

Antmen, A. (2019). Sanatçılardan yazılar ve açıklamalarla 20. yüzyıl batı sanatında akımlar. Sel Yayıncılık.

Badiou, A. (2019). Biyografi olarak felsefe. (M. Kayhan, Çev.). Pasajlar Dergisi, Alain Badiou, 3, 14-21.

Bahadır, A. (2020). Einfühlung kavramı bağlamında Tracey Emin’in “'1963-1995 yılları arasında uyuduğum herkes" ve "yatağım" eserlerinin çözümlenmesi. Social Sciences Research Journal, 9(2), 99-106. https://dergipark.org.tr/tr/download/article-file/1115251

Baker, U. (2015). Sanat ve arzu. (T. Açık, Ed.). İletişim Yayınları.

Başaran, A. (2000). Ísimsiz [Portre]. Apel. https://www.galleryapel.com/go.php?page=sergi\&sergiid=43

Başl1, Ş. (2005). Otobiyografi kuramına feminist bir yaklaşım. Littera Edebiyat Yazıları, 17, 91-103.

Behrengi, S. (2016). Küçük kara balık. Can Çocuk Yayınları.

Berksoy, S. (1963). Semiha Berksoy'un eşi Ercüment Siyavuşoğlu Beethoven'in Ay Işı̆̆ Sonatı'nı çalarken [Tablo]. Librakons. https://librakons.com/urun/semiha-berksoy-sergi-katalogu/

Bound Alberti, F. (2019). A biography of loneliness: The history of an emotion. Oxford University Press.

Bourriaud, N. (2005). İlişkisel estetik. (S. Özen, Çev.). Bağlam Yayınları.

Boyer, P., \& Wertsch, J. V. (2015). Zihinde ve kültürde bellek. (Y. Aşçı Dalar, Çev.). Türkiye İş Bankası Kültür Yayınlar1.

Chodorow, N. J. (2019). Duyguların gücü, psikanalizde, cinsiyette ve kültürde kişisel anlam. (J. Özata Dirlikyapan, Çev.). Metis Yayınları.

Çakır, F. (2004). Kemik porselen üretiminin incelenmesi, sanatsal çalışmalarda uygulanabilirliğinin araştırılması ve estetik niteliklerinin değerlendirilmesi (Tez No. 144344) [Sanatta Yeterlik, Hacettepe Üniversitesi, Sosyal Bilimler Enstitüsü]. Yükseköğretim Kurulu Başkanlığı Tez Merkezi.

Çallı, İ. (t.y.). Kadın Portresi [Tablo]. Hayata Dair. http://ressamlar.grafiksaati.com/ibrahim\%20calli/ibrahim $\% 20$ calli $\% 20 \mathrm{NU} \% 203 . j \mathrm{pg}$

Çelebioğlu, S. (2007). Türk Edebiyatında Modern Biyografinin Doğuşu (Tez No. 206282) [Yüksek Lisans Tezi, Boğaziçi Üniversitesi, Sosyal Bilimler Enstitüsü]. Yükseköğretim Kurulu Başkanlığı Tez Merkezi.

Çevik, Ç. (Ed.). (2017). Semiha Berksoy, Fikret Muallâ, iki aykırının mektupları. Kırmızı Kedi Yayınevi.

Da Vinci, L. (1490). Vitruvius Adamı [Çizim]. Wikipedia. https://tr.wikipedia.org/wiki/Vitruvius Adam\%C4\% $\underline{B 1}$

Da Vinci, L. (2021, Haziran 25). Zamanın ötesi [Ekran Görüntüsü]. Youtube https://www.youtube.com/watch?v= 9uVb4uI8hGQ\&t=1807s

Danto, A. C. (2019). Sıradan olanın başkalaşımı. (E. Berktaş ve Ö. Ejder, Çev.). Ayrıntı Yayınları.

Draaisma, D. (2018). Bellek metaforları, zihinle ilgili fikirlerin tarihi. (G. Koca, Çev.). Metis Yayınları.

Dutton, D. (2017). Sanat içgüdüsü, güzellik, zevk ve insan evrimi. (M. Turan, Çev.). Ayrıntı Yayınları. 
Edgü, F. (2013). Biçimler, renkler sözcükler. Sel Yayıncılık.

Elbeyoğlu, K. (2016). Kierkegaard'ın öznelliği ve ahlak görüşü. Y. Akış Yaman (Ed.), Kierkegaard, özne felsefe bilim ve sanat yazıları (s. 109-119) içinde. Çizgi Kitabevi.

Emin, T. (1995). Everyone I have ever slept with 1963-1995 [Enstalasyon]. Wikipedia. https://en.wikipedia.org/ wiki/Everyone_I_Have_Ever_Slept_With_1963\%E2\%80\%931995

Frolov, İ. (1991). Felsefe sözlüğ̈̈. (A. Çalışlar, Çev.). Cem Yayınevi.

Gintz, C. (2010). Başka yerde \& başka biçimde. Dost Kitabevi Yayınları.

Gompertz, W. (2020). Sanatçı gibi düşün, ... ve daha yaratıcı, daha verimli bir hayata kavuş. (S. Evren, Çev.). Yapı Kredi Yayınları.

Gül, D. (2003). Arzunun kanatlarl / Wings of desire [Enstalasyon]. Cappadox. http://cappadox.com/Festival/ cappadox $2017 ? \mathrm{p}=$ contemporary-artists-projects-events

Güner, E., \& Ataman, G. (2016). Bir ritüel olarak sanat: Richard Long. Akdeniz Sanat Dergisi, 9(19), 62-73. https://dergipark.org.tr/tr/download/article-file/275534

Hagman, G. (2010). The artist's mind, a psychoanalytic perspective on creativitiy, modern art and modern artists. Routledge.

Hamilton, N. (2007). Biography: A brief history. Harvard University Press.

Hartmann, H. (2020). Ben psikolojisi ve uyum sorunu. (B. Büyükkal, Çev.). Metis Yayınları.

Harvey, D. (1989). The condition of postmodernity, Blackwell.

Heidegger, M. (2011). Sanat eserinin kökeni. (F. Tepebaşılı, Çev.). De Ki Basım Yayım.

Hesse, E. (1966). Hang Up [Enstalasyon]. Artic. https://www.artic.edu/artworks/71396/hang-up

Hodge, S. (2020). Gerçekten bilmeniz gereken 50 sanat fikri. Domingo Yayınevi.

Holden, T. (2018). Şeyleşme ile tanıma arasında öznelerarasılık. (O. Kılıç, Çev.). Cogito, Neoliberalizmde öznellik, Odak: Kapitalist gerçeklik (s. 44-71) içinde. Yapı Kredi Yayınları.

Hopkins, D. (2018). Modern sanattan sonra, 1945-2017. (F. Candil Erdoğan, Çev.). Hayalperest Yayınevi.

Irigaray, L. (2006). Ben sen biz, farklılık kültürüne doğru. (S. Büyükdüvenci ve N. Tutal, Çev.). İmge Kitabevi.

İrgin, S. (2018). Bir yoksul sanat anlatısı. Sokak Kitapları Yayıncılık.

Kandinsky, W. (2020). Sanatta ruhsallık üzerine. (G. Ekinci, Çev.). Altıkırkbeş Yayın.

Kant, I. (2017). Fragmanlar. (O. Aruoba, Çev. ve Der.). Kırmızı Kedi Yayınevi.

Kemp, M. (2004). Leonardo. (H. Balkara, Çev.). Dost Kitabevi Yayınları.

Kruger, B. (1982). I can't look at you and breathe at the same time [Fotoğraf]. Printed Matter. https://www.printedmatter.org/catalog/50246/

Kuspit, D. (2010). Sanatın sonu. (Y. Tezgiden, Çev.). Metis Yayınları.

Lektorski, V. A. (2016). Özne, nesne, biliş. (Ş. Alpagut, Çev.). Yordam Kitap.

Lichtenstein, R. (1965). Brushstroke [Resim]. Tate. https://www.tate.org.uk/art/artworks/lichtenstein-brushstrokep07354

Long, R. (1967). A line made by walking [Fotoğraf]. Tate. https://www.tate.org.uk/art/artworks/long-a-line-madeby-walking-p07149

Maarit Mäkelä, J. B. (1999). Holly family [Seramik]. Maarit Mäkelä. https://www.maaritmakela.com/works/

Montaigne. (1993). Denemeler. (S. Eyuboğlu, Çev.). Cem Yayınevi.

Ortaylı, İ. (2011). Tarih yazıcılık üzerine. Cedit Neşriyat.

Read, H. (2020). Modern sanatın felsefesi. (E. Kök ve H. Orgun, Çev.). Hayalperest Yayınevi.

Rothko, M. (2020). Sanatçının gerçekliği. (E. B. Alpay, Çev.). Hayalperest Yayınevi.

Sherman, C. (2010). Untitled, Ísimsiz [Fotoğraf]. Wikiart. https://www.wikiart.org/en/cindy-sherman/untitled$\underline{2010-1}$ 
Sönmez, N. (2015). Şimdiki zamanın yanında ya da karşısında, Sanat üzerine yorumlar (1987-2014). Yapı Kredi Yayınlar1.

Şimşek, Ö. (2011). Sigaralı kadın [Fotoğraf]. Özlemsimsek. https://ozlemsimsek.com/selfportrait-as-modernturkish-art

Talay Turner, Z. (2021). Nietzsche'de tarih yazımı, hafıza ve aktif unutma. T. G. Esgün ve G. Salman (Eds.), Tanıdık ve yeni, Nietzsche'de aşırılık, yaşam, kendilik (s. 53-65) içinde. Pinhan Yayıncılık.

TDK. (1974). Özne. Türk Dil Kurumu Yayınları Türkçe Sözlük Sayı: 403 içinde. Bilgi Basımevi.

Tokmak, S. (Yazar ve Yönetmen). (2020, Mart 7). Özlem Şimşek (TRT 2, 2. Bölüm) [Tv Serisi Bölümü]. İzler/Suretler içinde. TRT Yapım Yayın. https://ozlemsimsek.com/news

Ünlü, A. (2015). Biyografi ve biyografik dram. Nota Bene Yayınları.

Vardar, İ. (2017). Dünyadan çıkış yolları / Way out from the World. Cappadox çağdaş sanat sergi kataloğu içinde. Mas Matbaacilık.

Woodman, F. (1977). Untitled [Fotoğraf]. Artnet. http://www.artnet.com/artists/francesca-woodman/3

Yörük, Y. (1985). Örnekli-uygulamall cümle bilgisi “söz dizimi”. Eğitim Yayınları. 